\title{
Proposed Plan for the K-Area Bingham Pump Outage Pit (643-1G)
}

by

E. Palmer

Westinghouse Savannah River Company

Savannah River Site

Aiken, South Carolina 29808

This paper was prepared in connection with work done under the above contract number with the U.S. Department of Energy. By acceptance of this paper, the publisher and/or recipient acknowledges the U.S. Government's right to retain a nonexclusive, royalty-free license in and to any copyright covering this paper, along with the right to reproduce and to authorize others to reproduce all or part of the copyrighted paper.

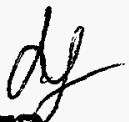


United States Department of Energy

Savannah River Site

Proposed Plan for the

K-Area Bingham Pump

Outage Pit (643-1G) (U)

WSRC-RP-97-106

Revision 1.1

June 1997

Westinghouse Savannah River Company Savannah River Site Aiken, SC 29808

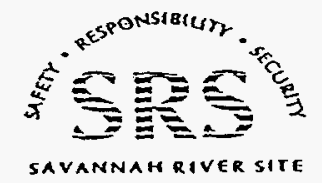

Prepared for the U. S. Department of Energy under Contract NO. DE-AC09-96-SR18500 


\section{DISCLAIMER}

This report was prepared as an account of work sponsored by an agency of the United States Government. Neither the United States Government nor any agency thereof, nor any of their employees, makes any warranty, express or implied, or assumes any legal liability or responsibility for the accuracy, completeness, or usefulness of any information, apparatus, product, or process disclosed, or represents that its use would not infringe privately owned rights. Reference herein to any specific commercial product, process, or service by trade name, trademark, manufacturer, or otherwise does not necessarily constitute or imply its endorsement, recommendation, or favoring by the United States Government or any agency thereof. The views and opinions of authors expressed herein do not necessarily state or reflect those of the United States Government or any agency thereof.

This report has been reproduced directly from the best available copy.

Available to DOE and DOE contractors from the Office of Scientific and Technical Information, P.O. Box 62, Oak Ridge, TN 37831; prices available from (615) 576-8401.

Available to the public from the National Technical Information Service, U.S. Department of Commerce, 5285 Port Royal Road, Springfield, VA 22161.

\begin{tabular}{|c|}
\hline $\begin{array}{c}\text { Printed in the United States of America } \\
\text { Prepared for } \\
\text { U. S. Department of Energy } \\
\text { and } \\
\text { Westinghouse Savannah River Company } \\
\text { Aiken, South Carolina }\end{array}$ \\
\hline
\end{tabular}




\section{DISCLAIMER}

Portions of this document may be illegible electronic image products. Images are produced from the best available original document. 
Table of Contents

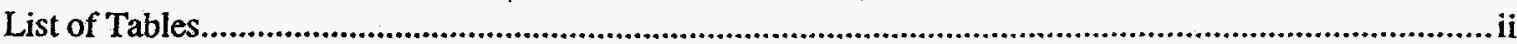

List of Figures

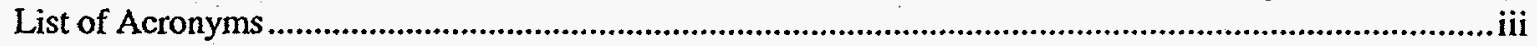

Executive Summary

Section I Introduction and Background................................................................................... 4

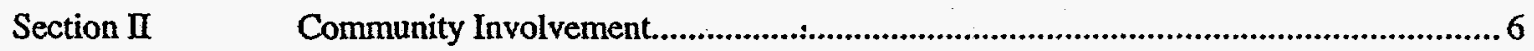

Section III Scope and Role of Operable Unit (Response Action) Within the Site Strategy .........................................................................................................

Section IV Media Specific Operable Unit - The K BPOP Unit.............................................. 8

Section IV.A Unit Description, History, and Media to be Addressed........................................................................... 8

Section IV.B $\quad$ Operable Unit Risks............................................................. 14

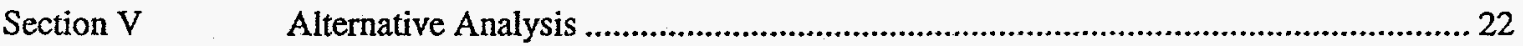

Section V.A Summary of the Alternatives for the K BPOP Source Control Operable Unit (Soils)

Section V.B Summary of the Alternatives for the K BPOP

Groundwater.

Section V.C Evaluation of the Alternatives and the Preferred

Alternative.

Section VI

Post-ROD Schedule

References

Glossary 
List of Tables

Page

Table 1 Estimated Radionuclide Inventory at the K-Area Bingham Pump Outage Pit (643-1G)... 12

Table 2 K BPOP Summary of Risk and Hazard Calculations for Exposure of Known On-Unit Industrial Workers.

Table 3 K BPOP Summary of Risk and Hazard Calculations for Exposure of Hypothetical Future On-Unit Residents and Industrial Workers

Table $4 \quad$ K BPOP Remedial Goals for Constituents of Concern by Receptor and Medium

Table 5 Comparative Analysis of Remedial Alternatives Considered for the K BPOP Source Control Operable Unit

\section{List of Figures}

Page

Figure 1 Location of the Reactor Areas at the Savannah River Site .........................................

Figure 2 Location of the K-Area Bingham Pump Outage Pit..................................................... 10

Figure $3 \quad$ K-Area Bingham Pump Outage Pit Dimensions.......................................................... 11

Figure 4 Soil Sampling Locations for the K-Area Bingham Pump Outage Pit.............................. 13

Figure 5 Groundwater Sampling Locations for the K-Area Bingham Pump Outage Pit................ 15

Figure 6 Conceptual Site Model for the K BPOP Waste Unit ...................................................... 17

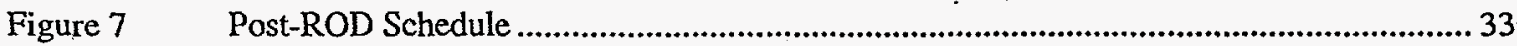




\section{List of Acronyms}

ARARs

ASCADTM $^{\text {TM }}$

BRA

CERCLA

CMI/RAR

cocs

COPCs

CFR

CSM

FS

DOE

EPA

FFA

K BPOP

LCOPCS

MCLs

NCP

RAOS

RBC

RCRA

RGOs

RI

ROD

SCDHEC

SRS

WSRC
Applicable or Relevant and Appropriate Requirements

Approved Standardized Corrective Action Design

Baseline Risk Assessment

Comprehensive Environmental Response, Compensation, and Liability Act

Corrective Measures Implementation/Remedial Action Report

Constituents of Concern

Constituents of Potential Concern

Code of Federal Regulations

Conceptual Site Model

Feasibility Study

United States Department of Energy

United States Environmental Protection Agency

Federal Facility Agreement

K-Area Bingham Pump Outage Pit

Leachable Constituents of Potential Concern

Maximum Contaminant Level

National Oil and Substances Pollution Contingency Plan

Remedial Action Objectives

Risk-Based Concentrations

Resource Conservation and Recovery Act

Remedial Goal Options

Remedial Investigation

Record of Decision

South Carolina Department of Health and Environmental Control

Savannah River Site

Westinghouse Savannah River Company 
This page intentionally left blank. 


\section{EXECUTIVE SUMMARY}

This Proposed Plan is issued by the U.S. Department of Energy (DOE), which functions as the lead agency for SRS remedial activities, and with concurrence by the U.S. Environmental Protection Agency (EPA) and the South Carolina Department of Health and Environmental Control (SCDHEC).

The purpose of this Proposed Plan is to describe the preferred remedial action for addressing the $\mathrm{K}$ Area Bingham Pump Outage Pit (K BPOP), (6431G), located at the Savannah River Site (SRS) in Aiken, South Carolina and to provide an opportunity for public input into the remedial action selection process. Section 117(a) of the Comprehensive Environmental Response, Compensation, and Liability Act (CERCLA) requires advertisement of the notice of proposed remedial actions (i.e., the Proposed Plan).

The $\mathrm{K} \cdot \mathrm{BPOP}$ is one of four Bingham Pump Outage Pit areas at the SRS, collectively referred to as the BPOP Approved Standardized Corrective Action Design (ASCAD ${ }^{\mathrm{TM}}$ ) waste unit group. The $\mathrm{K}$ BPOP has been designated as the lead waste unit in the ASCADTM BPOP waste unit group. $\mathrm{ASCAD}^{\mathrm{TM}}$ provides for complete characterization, technology evaluation, and remedial design of the $K$ BPOP lead unit within the BPOP waste unit group. This is followed by a focused characterization, technology validation, and unitspecific design for the secondary ASCADTM BPOP waste units. ASCAD ${ }^{\mathrm{M}}$ then provides for streamlining the design development process and projects focused technologies for remedial action for the secondary units based on the lead unit.

Under the ASCADTM strategy, the information from the lead site, K BPOP, will be used to define the site profile envelopes for comparison to the conditions that are expected to be found at the R/P/L BPOPs secondary sites. Envelopes are bounding conditions that should be met in order to apply the remedial alternative used on the lead site. The general concept is that all the Bingham Pump Outage Pits have similar operational histories, received similar wastes, and would probably have similar contamination profiles. The remedy selected, based on the extensive

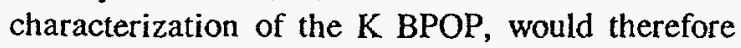
most likely be appropriate for the R/P/L BPOPs.
The secondary sites would be characterized to determine if their site profile matches the profile of the lead site. If the profile for the secondary site(s) matches the K BPOP profile, the preferred alternative for the $\mathrm{K} B P O P$ would be applied at the other Bingham Pump Outage Pits.

The Proposed Plan for the $K$ BPOP is also presenting the remedial strategy and the preferred alternatives for the R/P/L BPOPs. If the secondary site(s) profiles are within the $K$ BPOP site envelopes, the preferred alternative selected for the $\mathrm{K}$ BPOP will be implemented at the secondary site(s) by issuing a combined PP and ROD for the appropriate units.

The $K$ BPOP is located immediately south and outside of the $\mathrm{K}$ Reactor fence. The $\mathrm{K}$ Reactor is located in the west-central part of the SRS (approximately 4 miles east of the SRS boundary). Between. 1957 and 1958, miscellaneous construction debris generated by major modifications and repairs to the primary and secondary reactor cooling water systems was buried in the $\mathrm{K}$ BPOP. There were no pumps buried and no liquid waste was disposed of in the $\mathrm{K}$ BPOP. The radioactive contamination was less than $25 \mathrm{mR} / \mathrm{hr}$ with no detected alpha activity. Debris with radioactive contamination greater than $25 \mathrm{mR} / \mathrm{hr}$ was placed in the Burial Ground. The concentration of radioactivity buried in the $K$ BPOP is conservatively estimated at 1 Curie.

In 1958 , the K BPOP, which is approximately 400 feet long and 60 feet wide with a depth that varies from 9 to 14 feet (indicating a sloping pit base), was backfilled with approximately 4 feet of fill material. The site is now an open grassy area with the pit boundaries marked by orange ball markers and concrete monuments. Annual inspections are conducted for signs of soil subsidence, and sunken areas are filled to grade as needed.

The K BPOP Remedial Investigation Report with Baseline Risk Assessment (RI/BRA) (WSRC, 1997b) indicated that for an industrial land use scenario, external exposure to the soil $(0-1 \mathrm{ft})$ posed a risk of $3 \times 10^{-6}$ from cesium-137. This risk represents three excess cancers in a human population of one million.

In a residential land use scenario, external exposure to the soil $(0-1 \mathrm{ft})$ posed a risk of $1 \times 10^{-5}$ 
from cesium-137. This risk represents one excess cancer in a human population of one hundred thousand.

The risk driver for the KBPOP, based on the RI/BRA, is external exposure to cesium-137 in the soil at $0-1 \mathrm{ft}$. The maximum activity level of cesium-137 was $0.295 \mathrm{pCi} / \mathrm{g}$ which is within background concentrations around the waste unit and is likely to be from global fallout.

It was concluded that none of the constituents detected in the soil at the $K$ BPOP have the potential for adverse effects on the animal inhabitants that may use the unit as a foraging area. It's also unlikely that the constituents would cause an adverse effect on the ecological community. Therefore, there is no need for remediation of the $\mathrm{K}$ Bingham Pump Outage Pit (K BPOP) from an ecological standpoint.

The RI concluded that the $K$ BPOP is not impacting groundwater. Constituents were not observed to have migrated horizontally and clayey zones underneath the base of the pit will limit vertical migration potential.

The K BPOP Feasibility Study (FS) (WSRC, 1997a) identified an extensive suite of potential technologies and process options for both soils and groundwater that could be used at any BPOP in the ASCAD ${ }^{\text {TM }}$ BPOP waste unit group. The development and screening of alternatives. section in the K BPOP FS could also apply to any unit in the BPOP waste unit group. The detailed analysis section of the K BPOP FS was specific to the $K$ BPOP.

Based on the conclusion of the $\mathrm{K}$ BPOP RI/BRA (WSRC, 1997b), there was no groundwater contamination which would pose a current or future threat to human health or the environment. Therefore, there were no groundwater alternatives considered in the Feasibility Study.

The K BPOP FS (WSRC, 1997a) included detailed analyses of six alternatives for the K BPOP soils. These alternatives were:

\section{$\underline{\text { Soils }}$}

1. No Remedial Action

2. Institutional Controls (Access and Deed Restrictions/Notifications)
3. Placement of a Soil Cover

4. In-Situ Solidification of Soil and Debris, Soil Cover

5. Excavate Soil and Debris, Solidify/Stabilize, Backfill Treated Soil and Debris, Soil Cover

6. Excavate Soil and Debris, Dispose in E-Area Vaults or Soil/Debris Consolidation Facility (if applicable)

The preferred alternative for the $\mathrm{K}$ BPOP soils is Alternative 2 - Institutional Controls (Access and Deed Restrictions/Notifications), which will restrict this land to future industrial use. This alternative would prohibit residential use of this area. The risk levels present at the K BPOP are at the lower end of the risk range. However, the presence of buried debris with fixed contamination requires Institutional Controls in- order to be protective from unauthorized removal/ excavation concerns.

Implementation of the Institutional Controls alternative will require both near- and long-term actions. For the near-term, signs will be posted at the waste unit which indicate that this area was used for disposal of waste material and contains buried waste. In addition, existing SRS access controls will be used to maintain the use of this site for industrial use only.

In the long-term, if the property is ever transferred to non-federal ownership, the U.S. Government will, in compliance with CERCLA 120(h), create a deed for the new property owner. The deed shall include notification disclosing former waste management and disposal activities as well as remedial actions remedial actions taken on the site. The deed notification shall, in perpetuity, notify any potential purchaser that the property has been used for the management and disposal of construction debris and other materials, including hazardous substances.

The deed shall also include deed restrictions precluding residential use of the property. However, the need for these deed restrictions may be reevaluated at the time of transfer in the event that contamination no longer poses an unacceptable risk under residential use. 
Throughout the period of Federal ownership, as well - as for any future ownership, under Institutional Controls (Alternative 2), there will be no risk greater that $3 \times 10^{-6}$ to the hypothetical future industrial worker. Furthermore, there will be no risk to the environment.

Community involvement in the remedial alternative selection process for the K BPOP is strongly encouraged. All submitted comments will be reviewed and considered. A Responsiveness Summary will be prepared to address issues raised during the public comment period and it will be made available with the Record of Decision (ROD). The final ROD documents the final decision for the K BPOP waste unit. 


\section{SECTION I}

\section{INTRODUCTION AND BACKGROUND}

\section{Introduction}

This Proposed Plan is issued by the U.S. Department of Energy (DOE), which functions as the lead agency for SRS remedial activities, and with concurrence by the U.S. Environmental Protection Agency (EPA) and the South Carolina Department of Health and Environmental Control (SCDHEC). The purpose of this Proposed Plan is to describe the preferred remedial alternative for addressing the K-Area Bingham Pump Outage Pit (643-1G) (K BPOP) located at the Savannah River Site (SRS) in Aiken, South Carolina and to solicit public comment on the preferred alternative.

On December 21, 1989, SRS was included on the National Priorities List. This inclusion created a need to integrate the established RFI Program with CERCLA requirements to provide for a focused environmental program. In accordance with Section 120 of CERCLA, DOE has negotiated a Federal Facility Agreement (FFA, 1993) with EPA and SCDHEC to coordinate remedial activities at SRS into one comprehensive strategy which fulfills these dual regulatory requirements.

CERCLA requires that the public be given an opportunity to review and comment on the proposed remedial alternative. Public participation requirements are listed in Sections 113 and 117 of CERCLA. These requirements include establishment of an Administrative Record File that documents the selection of remedial alternatives and allows for review and comment by the public regarding those alternatives (see Section II). The Administrative Record File must be established at or near the facility at issue. The SRS Public Involvement Plan (DOE, 1994) is designed to facilitate public involvement in the decision-making process for permitting, closure, and the selection of remedial alternatives. Section 117(a) of CERCLA, as amended, requires advertisement of the notice of any proposed remedial action and provides the public an opportunity to participate in the selection of a remedial action.

This Proposed Plan is a summary of the Administrative Record File leading to the preferred remedial alternative. This Proposed Plan presents the preferred alternative and the rationale for selecting the alternative. Community involvement in consideration of this evaluation of alternatives for the $\mathrm{K}$ BPOP is strongly encouraged. Following the public comment period, a Responsiveness Summary will be prepared to address significant issues raised during the comment period. The final decision will be made only after the public comment period has ended and all comments submitted have been reviewed and considered.

In order to gain a better understanding of CERCLA activities as they pertain to the K BPOP, the public is encouraged to review the Administrative Record File for this unit. Refer to Section II of this document for information regarding availability and access.

The final selection of the remedial alternative, that will satisfy the FFA requirements, will be made by DOE, in consultation with EPA and SCDHEC, only after the public comment period has ended and all comments submitted have been reviewed and considered.

\section{Background}

SRS occupies approximately 310 square miles of land adjacent to the Savannah River, principally in Aiken and Barnwell counties of South Carolina. SRS is a secured U.S. Government facility with no permanent residents. SRS is located approximately 25 miles southeast of Augusta, Georgia and 20 miles south of Aiken, South Carolina.

SRS is owned by the U.S. DOE. Management and operating services are provided by Westinghouse Savannah River Company (WSRC). SRS has historically produced tritium, plutonium, and other special nuclear materials for national defense. Chemical and radioactive wastes are by-products of nuclear material production processes. Hazardous substances, as defined by CERCLA, are currently present in the environment at SRS.

The $\mathrm{K}$ BPOP, 643-1G, is not subject to RCRA permit modification per the Federal Facility Agreement for the SRS, Appendix C. The Federal Facility Agreement does list the K BPOP, 643-1G, as a CERCLA unit requiring further evaluation 
using an investigation/assessment process to determine the actual or potential impact to human health and the environment.

Community involvement in consideration of this evaluation of alternatives for the $\mathrm{K}$ BPOP is strongly encouraged. All submitted comments will be reviewed and considered. A Responsiveness Summary will be prepared to address issues raised during the public comment period and it will be made available in the $K$ BPOP Record of Decision (ROD). The ROD documents the final decision for the unit. Specific details on community participation in the corrective action selection process are provided in Section II. 


\section{SECTION II}

\section{COMMUNITY INVOLVEMENT}

This document summarizes information that is provided in greater detail in the FFA Administrative Record File, which is available for review by the public at the following locations:

U. S. Department of Energy

Public Reading Room

Gregg-Graniteville Library

University of South Carolina-Aiken

171 University Parkway

Aiken, South Carolina 29801

(803) 641-3465

Thomas Cooper Library

Government Documents Department

University of South Carolina

Columbia, South Carolina 29208

(803) $777-4866$

Similar information is available through the repositories listed below:

Reese Library

Augusta State University

2500 Walton Way

Augusta, Georgia 30910

(706) 737-1744

Asa H. Gordon Library

Savannah State University

Tompkins Road

Savannah, Georgia 31404

(912) $356-2183$

The public will be notified of a public comment period through mailing of the SRS Environmental Bulletin, a newsletter sent to approximately 3500 citizens in South Carolina and Georgia, and through notices in the Aiken. Standard, the Allendale Citizen Leader, the Augusta Chronicle, the Bamwell People-Sentinel, and The State newspapers. The public comment period will also be announced on local radio stations.

DOE will provide opportunity for a public meeting during the public comment period if interest is expressed. The public would be notified of the date, time, and location. At the meeting, the proposed action would be discussed and questions about the action would be answered. Written and oral comments will be accepted and considered prior to a final decision. To request a public meeting during the public comment period, to obtain more information concerning this Proposed Plan, or to submit written comments contact:

Mary A. Flora

Public Involvement

Westinghouse Savannah River Company

Savannah River Site

Building 730-2B, Room 131

Aiken, South Carolina 29808

(803) $952-6852$

Following the public comment period, a Record of Decision will be signed. The Record of Decision will detail the remedial alternative chosen for the site and will include responses to oral and written comments received during the public comment period in the Responsiveness Summary. 


\section{SECTION III}

\section{SCOPE AND ROLE OF OPERABLE UNIT (RESPONSE ACTION) WITHIN THE SITE STRATEGY}

The overall strategy for addressing the $\mathrm{K}$ Bingham Pump Outage Pit (K BPOP) was to: (1) characterize the waste unit delineating the nature and extent of contamination and identifying the media of concern (perform the RI); (2) perform a baseline risk assessment to evaluate media of concern, constituents of concern (COCs), exposure pathways, and characterize potential risks; and (3) evaluate and perform a final action to remediate, as needed, the identified media of concern.

The K BPOP is one of four Bingham Pump Outage Pit areas at the SRS, collectively referred to as the BPOP Approved Standardized Corrective Action Design (ASCADTM) waste unit group. Under the $A S C A D^{\text {TM }}$ strategy, the information from the lead site, K BPOP, will be used to define the site profile envelopes for comparison to the conditions that are expected to be found at the R/P/L BPOPs secondary sites. If the secondary site(s) profiles are within the $K$ BPOP site envelopes; the preferred alternative selected for the K BPOP will be implemented at the secondary site(s) by issuing a combined PP and ROD for the appropriate units.

The K BPOP is an operable unit located within the Pen Branch Watershed along with several other KArea waste units. No wetlands or creeks are adjacent to the area surrounding the $\mathrm{K}$ BPOP. Several source control and groundwater operable units within this watershed will be evaluated to determine impacts, if any, to associated streams and wetlands. SRS will manage all source control and groundwater operable units to minimize impact to the watershed.

Based on characterization and risk assessment information, the $\mathrm{K}$ BPOP does not impact the watershed. Upon disposition of all source control and groundwater operable units within this watershed, a final, comprehensive evaluation of the watershed will be conducted to determine whether any additional actions are necessary for the watershed. The proposed action for the $\mathrm{K}$ BPOP soils and groundwater aquifer is a final action. 


\section{SECTION IV}

\section{MEDIA SPECIFIC OPERABLE UNIT - THE K BPOP UNIT}

\section{Section IV.A Unit Description, History, and} Media to be Addressed

\section{Unit Description and Location}

The K-Reactor (Figure 1) is located in the westcentral portion of the SRS, approximately 4 miles east of the nearest SRS boundary. The $K$ Bingham Pump Outage Pit (K BPOP), 643-1G, is situated immediately south and outside of the K-Reactor fence line (Figure 2) and is approximately 400 feet in length and 60 feet in width (Figure 3 ).

Surface water drainage ditches surround the $K$ BPOP to the north, west, and south. These ditches collect and redirect runoff water to reduce erosion. As depicted in Figure 2, the K BPOP is located on the west side of a small topographical high. Consequently, surface water drainage from other areas has little or no effect on the surface of the $K$ BPOP. Generally, no surface water is found in the drainage ditches.

The $\mathrm{K}$ BPOP is situated in the Tobacco Road formation which extends from ground surface to a depth of 95 feet below ground surface. The Tobacco Road formation is composed of dark red to tan, very fine to fine sandy clay and clayey sands with laminated tan and purple, silty, clayey very fine to medium sands.

The groundwater flow direction is to the southwest across the K BPOP and the groundwater flow rate for the Water Table Aquifer beneath the K BPOP is estimated at approximately $91.25 \mathrm{ft} /$ year.

\section{History of the Unit}

Between 1957 and 1958, miscellaneous construction debris generated by major modifications and repairs to the primary and secondary reactor cooling water systems was buried in the $\mathrm{K}$ BPOP. There were no pumps buried and no liquid waste was disposed of in the $\mathrm{K} B P O P$. The depth of excavation at the $\mathrm{K} B P O P$ ranged from 9 to 14 feet, which indicates a sloping pit base (this is consistent with the use of the pit for disposal purposes). The radioactive contamination was less than $25 \mathrm{mR} / \mathrm{hr}$ with no detected alpha activity. Debris with radioactive contamination greater than $25 \mathrm{mR} / \mathrm{hr}$ was placed at the SRS Burial Ground. Table 1 illustrates the estimated inventory of activity at the time of burial and as of December 31, 1995.

The K BPOP was backfilled with approximately four feet of fill material in 1958 and is now an open grassy area marked by orange ball markers and concrete monuments. Annual inspections are conducted for signs of soil subsidence; and, sunken areas are filled to grade as needed. Two monitoring wells were installed for the July 1996 Confirmatory Sampling Program as part of the $\mathrm{K}$ BPOP Remedial Investigation.

\section{Media Assessment}

The Remedial Investigation Report with Baseline Risk Assessment for the K-Area Bingham Pump Outage Pit (643-1G) (U) (WSRC, 1997b) contains detailed analytical data for all of the environmental media samples taken: in the characterization of the unit.

The $\mathrm{K}$ BPOP characterization proceeded in a phased approach to collect soil and groundwater data to evaluate the nature and extent of contamination and the poteritial risk. A total of 36 soil, 6 groundwater, and 6 geotechnical samples were collected. The following summaries for the soils and groundwater are based on the screening that was completed for the remedial investigation and not the baseline risk assessment. The baseline risk assessment results are discussed separately.

\section{$\underline{\text { Soils }}$}

During the $\mathrm{K}$ BPOP remedial investigation, unitspecific background sampling was conducted at three soil boring locations (KBP1, KBP2, and KBP3) positioned upgradient from the pit (Figure 4). For the soil borings, composite samples were collected from each of five intervals $(0-1 \mathrm{ft}, 10-12$ $\mathrm{ft}, 12-14 \mathrm{ft}, 14-16 \mathrm{ft}$, and 16-18 ft). The background soil samples were divided into data sets: surface soil (0-1 ft) and deep soil ( $>9 \mathrm{ft})$.

Figure 4 also graphically depicts the thirty-six soil samples which were collected from the three pit borings (KBP6, KBP9, and KBP11) and the six 
Figure 1. Location of the Reactor Areas at the Savannah River Site.

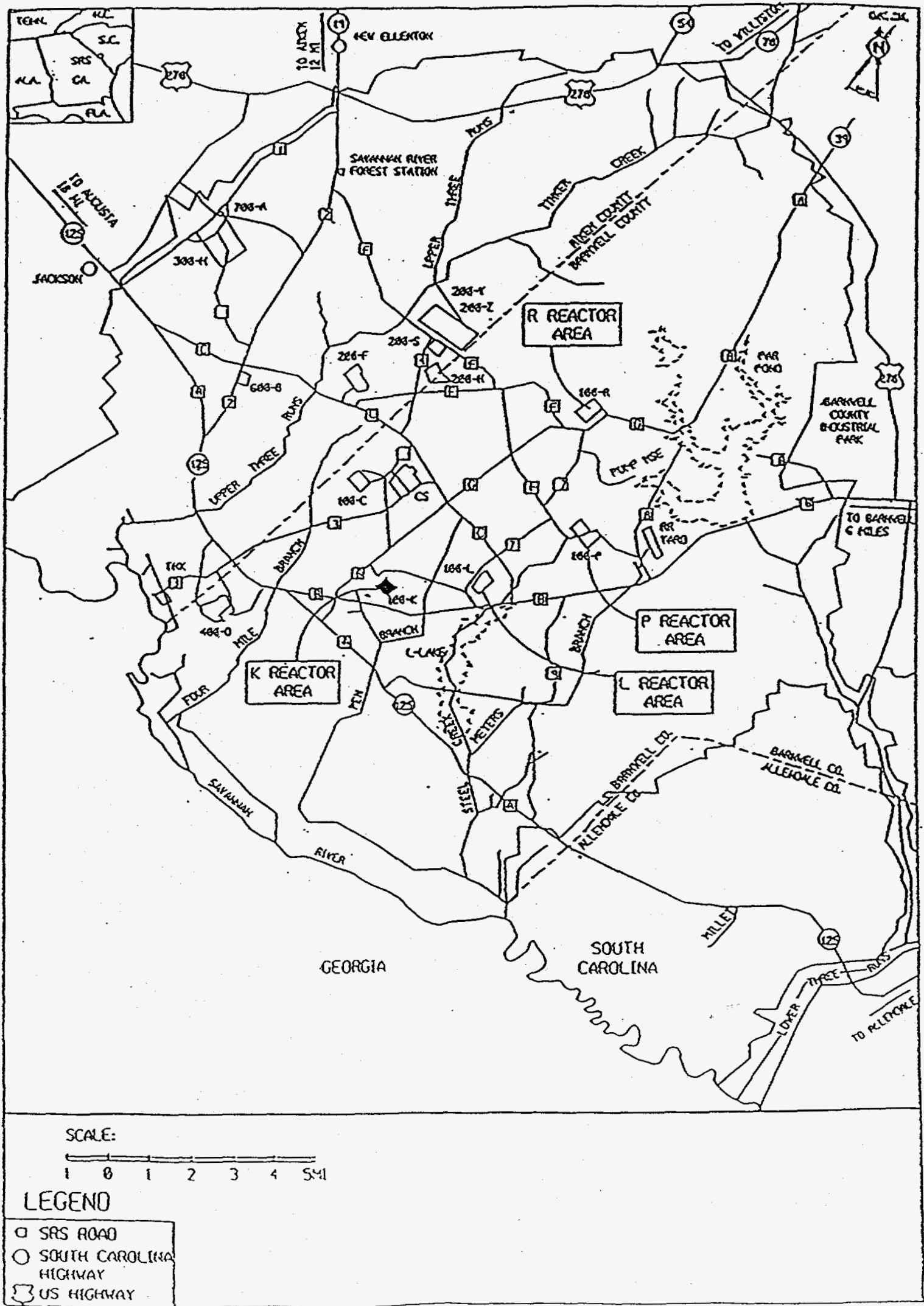


Figure 2. Location of the K-Area Bingham Pump Outage Pit.

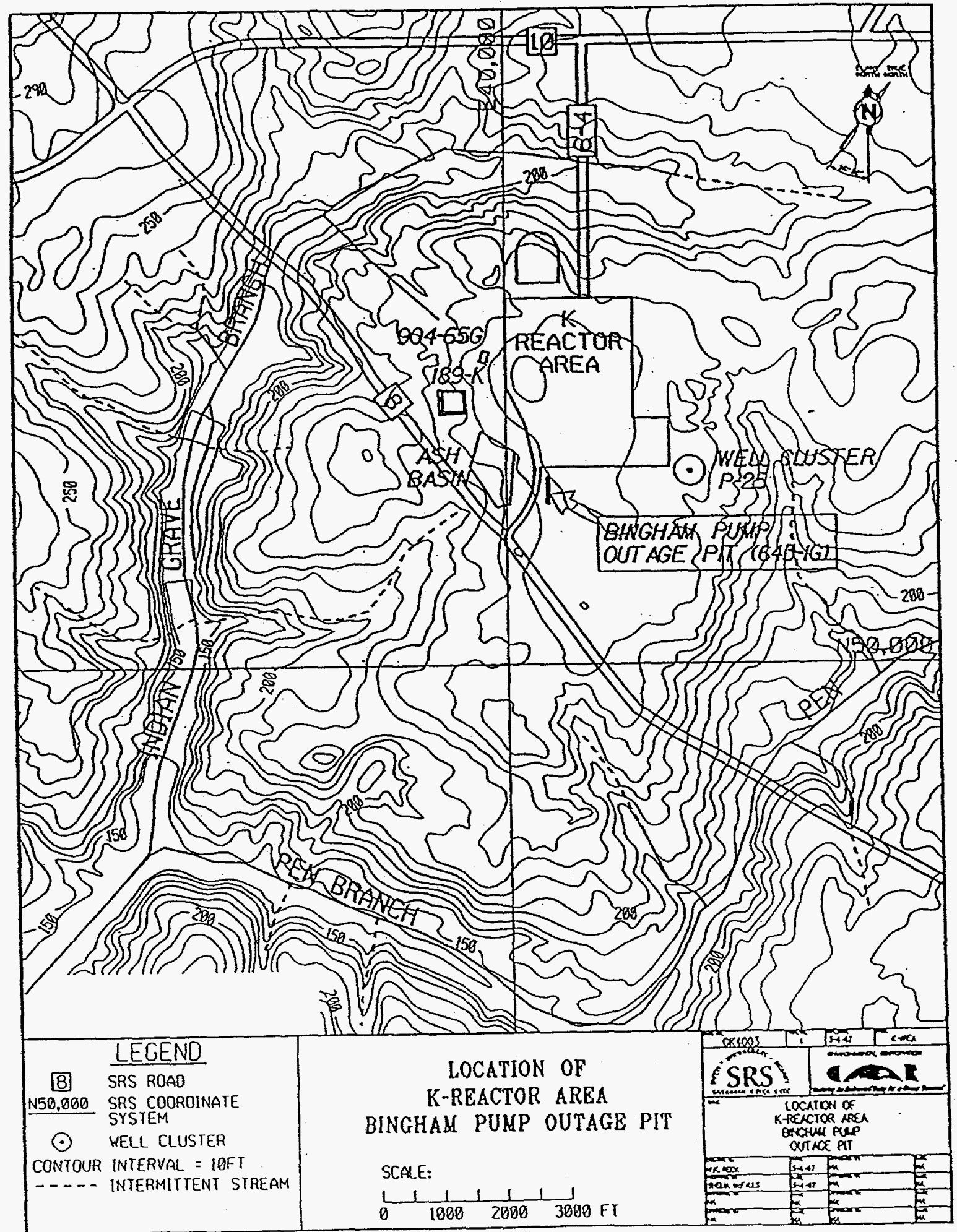


Figure 3. K-Area Bingham Pump Outage Pit Dimensions.

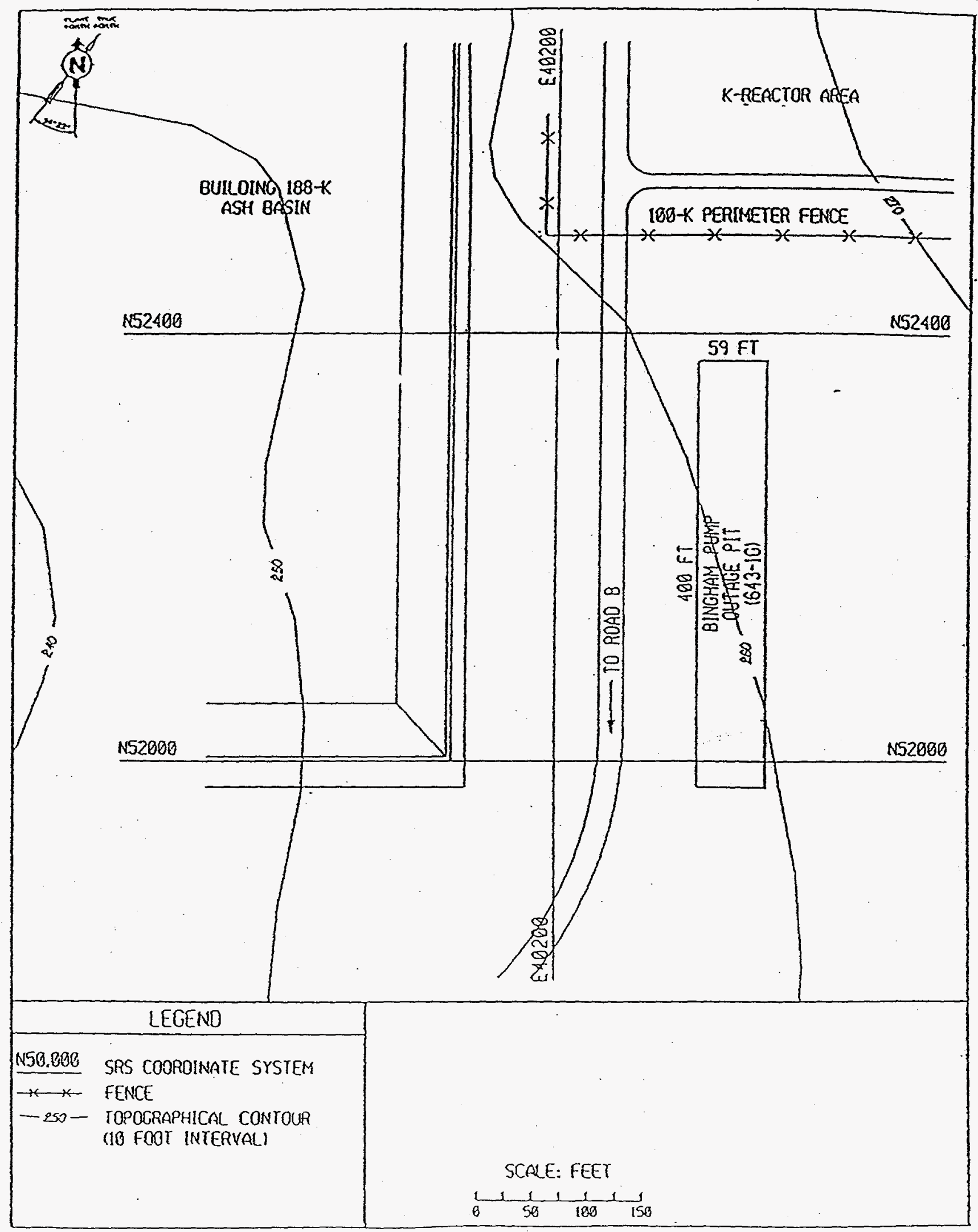


Table 1.Estimated Radionuclide Inventory at the K-Area Bingham Pump Outage Pit (643-1G).

\begin{tabular}{|l|c|c|}
\hline \multicolumn{1}{|c|}{ Radionuclide } & Inventory at Burial (Curies) & $\begin{array}{c}\text { Inventory Corrected for Decay Through } \\
\text { December 31, 1995 (Curies) }\end{array}$ \\
\hline Cobalt-60 & 0.172 & $1.34 \times 10^{-3}$ \\
\hline Strontium-90 & 0.112 & $4.70 \times 10^{-2}$ \\
\hline Ruthethenium-103/106 & 0.130 & $1.12 \times 10^{-12}$ \\
\hline Cesium-137 & 0.414 & $1.75 \times 10^{-1}$ \\
\hline Promethium-147 & 0.172 & $7.50 \times 10^{-6}$ \\
\hline Total & 1.00 & $2.23 \times 10^{-1}$ \\
\hline
\end{tabular}


Proposed Plan for the K-Area Bingham Pump Outage Pit (643-1G)

Savanuah River Site

WSRC-RP-97-106

Revision 1.1

June 1997

Paige 13 of 36

Figure 4. Soil Sampling Locations for the K-Area Bingham Pump Outage Pit.




perimeter borings (KBP4, KBP5, KBP7, KBP8, $\mathrm{KBP} 10$, and $\mathrm{KBP} 12$ ).

For soils, the results from the $K$ Bingham Pump Outage Pit (K BPOP) sample analyses indicate that minor concentrations/ activities of constituents have migrated from the pit into the surrounding soil horizons; however, horizontal migration is limited to the boundaries of the pit and vertical migration is limited to the upper clayey zones.

The geotechnical and geologic data indicate that a less permeable zone is present underneath the pit that will inhibit less mobile constituents from migrating vertically and potentially impacting the groundwater.

\section{Groundwater}

A total of six groundwater samples were collected from the water table aquifer in the vicinity of the $\mathrm{K}$ BPOP. These include two background samples (KH1 and $\mathrm{KH} 4$ ), an additional upgradient sample $(\mathrm{KH} 3)$, and three down- or sidegradient samples (KH2, KH5; and KH6) (Figure 5). The initial groundwater samples were collected using temporary piezometers.

The metal concentrations were unusually high and were detected in both upgradient and downgradient sampling locations for the $K$ Bingham Pump Outage Pit (K BPOP) and are interpreted to be directly related to the sampling protocol used. These unusually high metal concentrations are the indirect result of the high turbidity associated with each sample. To demonstrate the validity of this interpretation, Confirmatory Characterization was conducted in July 1996, during which two RCRA-standard groundwater monitoring wells (one upgradient and one downgradient) were installed at the K BPOP. Results from the sampling of these wells support the interpretation that the $\mathrm{K}$ BPOP has not impacted the groundwater and that the metal constituents detected are naturally occurring.

The detection of iodine- 129 is suspect because no other fission products (i.e., technetium-99 and strontium-90) were detected in this temporary piezometer sample and because false positives are often associated with gamma PHA. Moreover, this detection is also suspect because iodine-129 was not detected in the groundwater samples taken from the RCRA-standard monitoring wells which were installed and sampled during the $K$ BPOP Confirmatory Characterization.

\section{Soil Leachability Analysis}

Soil leachability modeling was performed with a detailed unit-specific model. The model calculates concentrations of soil water constituents at the base of the vadose zone. Groundwater concentrations are then calculated from these values by applying the groundwater dilution factor. The nature of the input data and the analytical model assumptions are such that the estimates of groundwater concentrations are conservative.

The leachable constituents of potential concern (LCOPCs) for the $\mathrm{K}$ BPOP include metals, inorganic compounds, radionuclides, organics, and pesticides with the predominant risk driver for the hypothetical future on-unit resident and on-unit worker being iodine-129.

For the hypothetical future on-unit resident and on-unit worker, the cancer risk for iodine-129 leaching to the groundwater is approximately $10^{-5}$. This risk is based on one detection $(0.203 \mathrm{pCi} / \mathrm{g})$ out of three soil samples analyzed. The iodine- 129 result is highly questionable and below the reported detection limit for iodine-129. Using the highly questionable value with the conservative soil leachability models overestimates the future groundwater values. Therefore, corrective action for the groundwater is not warranted based upon the soil leachability analysis.

\section{Section IV.B Operable Unit Risks}

As a component of the remedial investigation process, a baseline risk assessment was prepared for the $\mathrm{K}$ BPOP. The baseline risk assessment consists of human health and ecological risk assessments. Summary information for the human health and ecological risk assessments follows.

\section{Human Health Risk Assessment}

As part of the investigation/assessment process for the $\mathrm{K}$ BPOP, a risk assessment was performed using the data generated during the assessment phase. Detailed information regarding the development of constituents of potential concern, 
Figure 5. Groundwater Sampling Locations for the K-Area Bingham Pump Outage Pit.

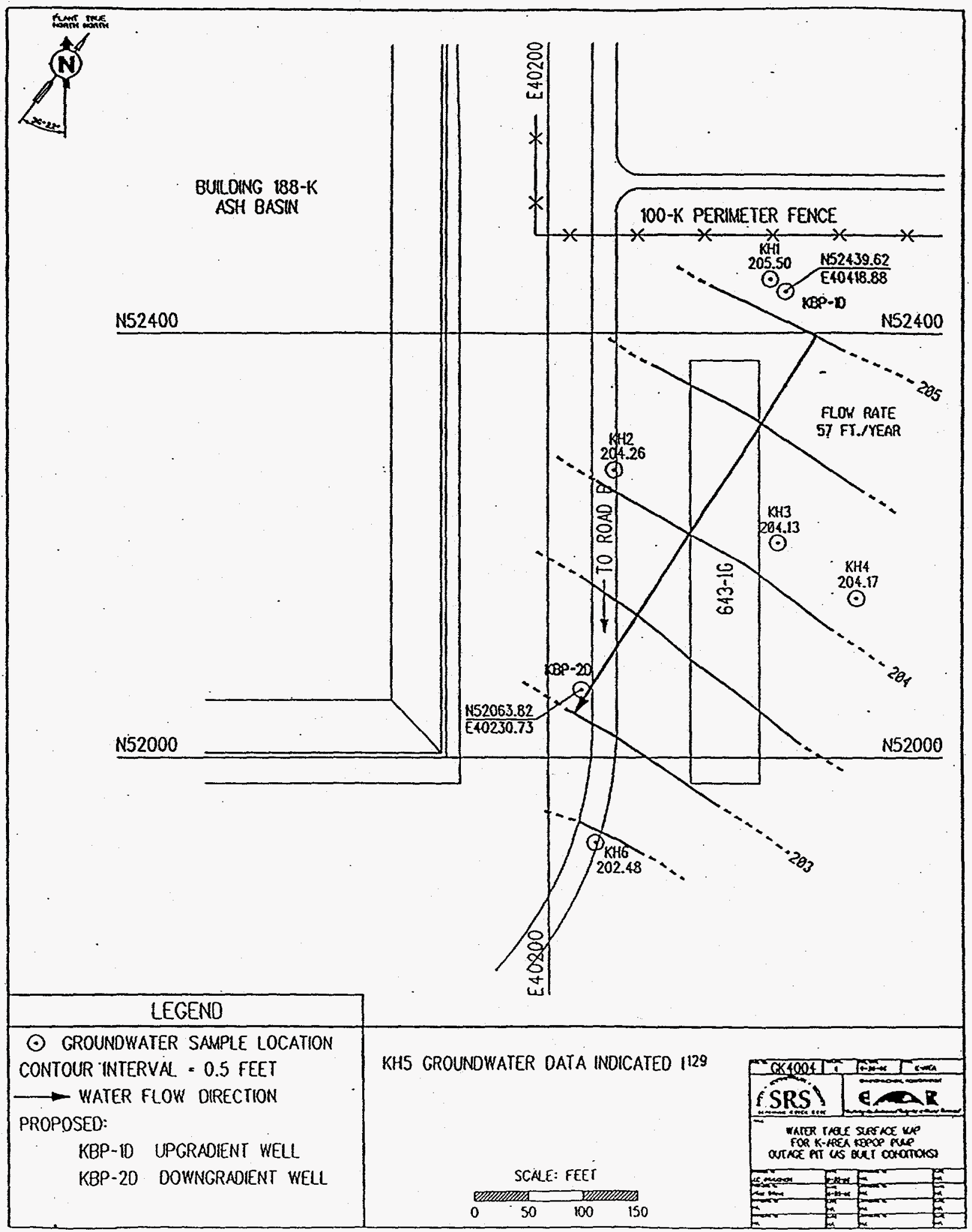


the fate and transport of constituents, and the risk assessment can be found in the Remedial Investigation Report with Baseline Risk Assessment for the K-Area Bingham Pump Outage Pit (643-IG) (U) (WSRC, 1997b).

\section{Conceptual Site Model}

A refined Conceptual Site Model (CSM) was developed for the $K$ BPOP waste unit that identifies primary sources, primary contaminated media, migration pathways, exposure pathways, and potential receptors for the waste unit. The CSM is presented in Figure 6 and is based on the results presented in the Remedial Investigation Report with Baseline Risk Assessment for the KArea Bingham Pump Outage Pit (643-1G) (U) (WSRC, 1997b) which is available in the Administrative Record.

The potential risk associated with the $K$ BPOP is restricted to the soils at the unit. Contaminants found in groundwater are suspect due to the use of temporary piezometers or are ubiquitous given the nature of the SRS.

\section{Current Land Use}

Under the current land use scenario, carcinogenic risks and noncarcinogenic hazards from nonradiological and radiological constituents are characterized for exposure of a known (current) on-unit industrial worker to surface soil and air. The criteria used to evaluate potential impacts to human health are a cancer risk greater than $1.0 \times 10^{-6}$ and a Hazard Index of 1.0. Table 2 presents the summary of risk and hazard calculations for the known on-unit worker.

There were no nonradiological constituents of concern identified for the current on-unit industrial worker; therefore, there were no nonradiological carcinogenic risk or hazard for the current on-unit worker.

A total carcinogenic (cancer) risk of $7 \times 10^{-7}$ was derived for the known on-unit worker. This cancer risk is below $1 \times 10^{-6}$, indicating an acceptable cancer risk.
Future Land Use

Under the future land use scenario, carcinogenic risks and noncarcinogenic hazards associated with nonradiological constituents were calculated for exposure of the hypothetical on-unit worker to surface soils, air, and groundwater. Carcinogenic risks and noncarcinogenic hazards for these same factors, plus homegrown produce, were then calculated for the hypothetical on-unit resident (adult and child). Radiological risks were calculated for exposure of the hypothetical resident and worker to surface soils, air, groundwater, homegrown produce (on-unit resident only), and external radiation.

The results of the RI/BRA indicated that Cesium137 was the only soil (0-1 ft.) constituent of concern for the future on-unit industrial worker and resident. The activity level of Cesium-137 that was present at the K BPOP was likely due to global fallout.

Table 3 presents the summary of risk and hazard calculations for the hypothetical future on unit residents (adult/child) and workers.

\section{- Nonradiological Carcinogenic Risk}

The total cancer risk for nonradioactive carcinogens for the hypothetical on-unit industrial worker and resident exposed to surface soil (0-1 ft) and groundwater was $2 \times 10^{-6}$ and $6 \times 10^{-6}$, respectively. Bis(2-ethylhexyl)phthalate led to the nonradiological carcinogenic risk. However, its presence is suspect since the phthalates are common laboratory contaminants.

\section{- Noncarcinogenic Hazard}

The total noncarcinogenic hazard index (HI) for the hypothetical on-unit industrial worker and resident exposed to surface soil $(0-1 \mathrm{ft})$ and groundwater was 0.7 and 4.0. This was due primarily to the ingestion of manganese. The maximum on-unit concentration of manganese was less than a factor of two greater than the 


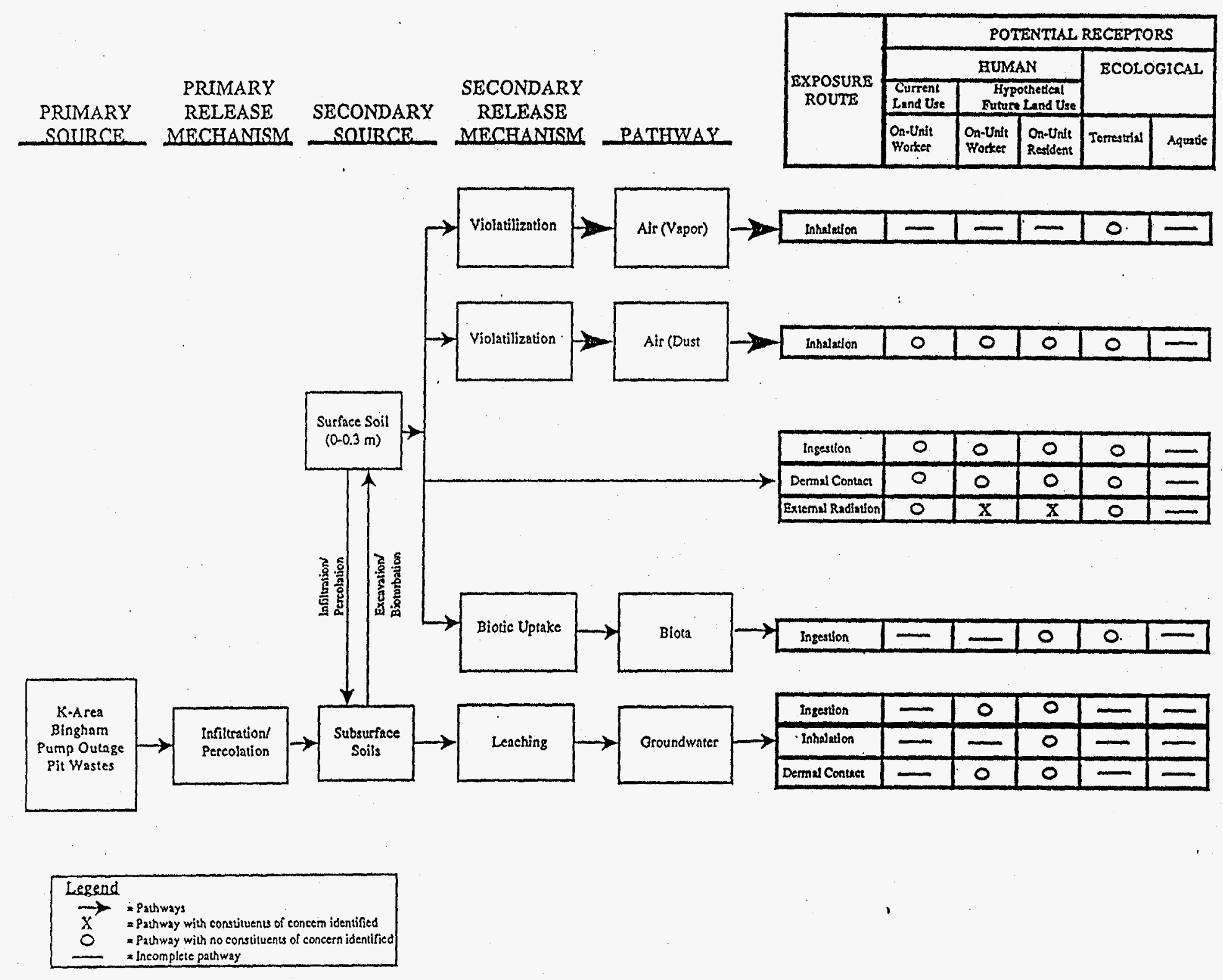


Table 2. K BPOP Summary of Risk and Hazard Calculations for Exposure of Known On-Unit Industrial Workers.

\begin{tabular}{|c|c|c|c|c|c|}
\hline \multirow[b]{3}{*}{ Matrix } & \multicolumn{5}{|c|}{ K BPOP Soil $(0-1 \mathrm{ft})$} \\
\hline & \multicolumn{2}{|c|}{ Exposure to Radionuclides } & \multicolumn{3}{|c|}{ Exposure to Chemicals } \\
\hline & Route & Risk & Route & Risk & Hazard \\
\hline Soil $(0-1 \mathrm{ft})$ & Ingestion & 1.3E-11 & Ingestion & NC & $\mathrm{NC}$ \\
\hline & Dermal & $1.6 \mathrm{E}-13$ & Dermal & $\mathrm{NC}$ & NC \\
\hline & Inhalation (P) & $1.2 \mathrm{E}-16$ & Inhalation (P) & $\mathrm{NC}$ & NC \\
\hline & External & 7.3E-07 & Inhalation (V) & NC & NC \\
\hline Totals & & 7E-07 & & $\mathrm{NC}$ & NC \\
\hline
\end{tabular}

P - Particulates

$\mathrm{V}$ - Volatiles

NC - Not Calculated 
Table 3. K BPOP Summary of Risk and Hazard Calculations for Exposure of Hypothetical Future On-Unit Residents and Industrial Workers.

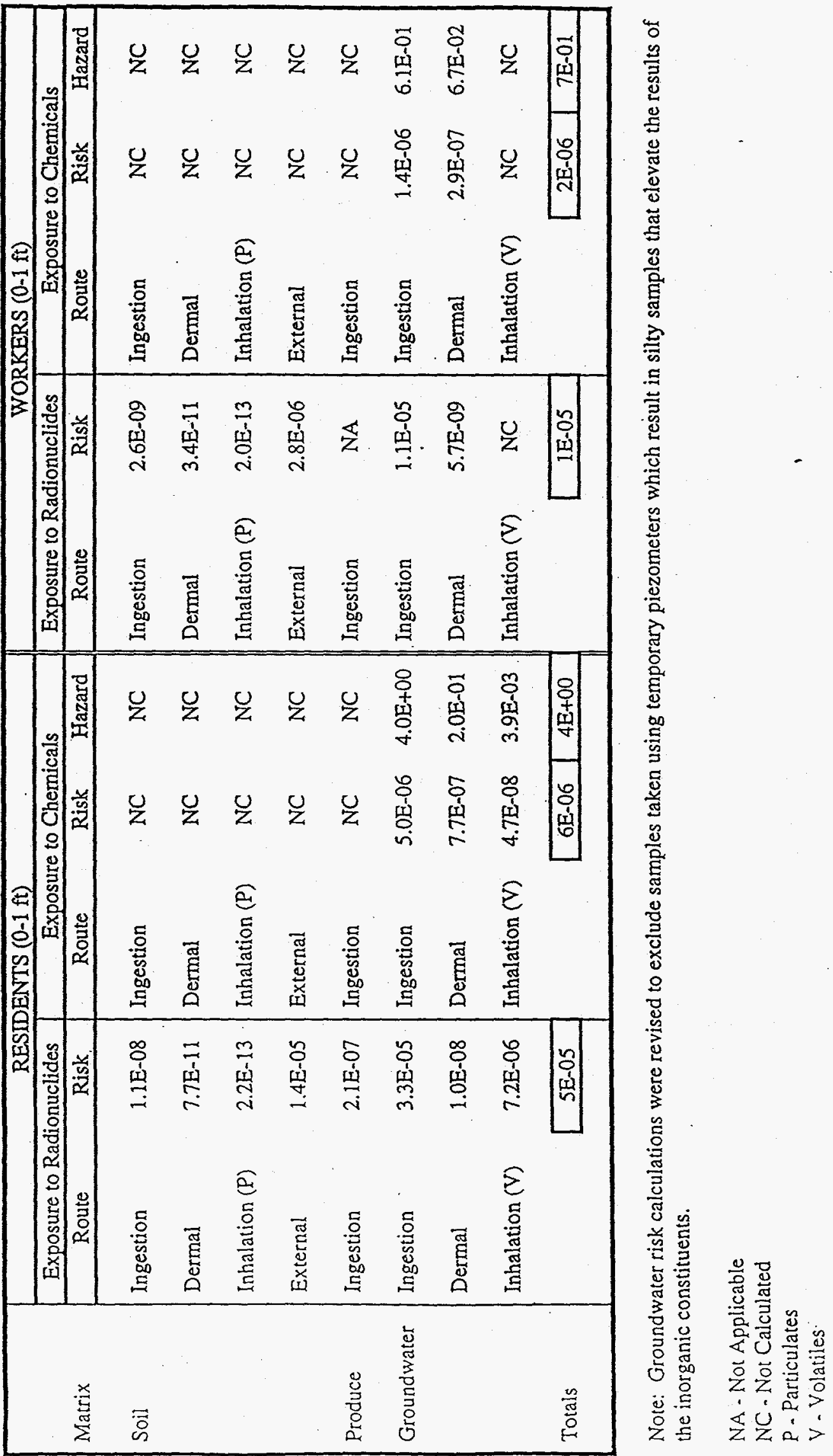


background screening value, indicating that the concentration likely reflects background conditions. Although the new round of sampling did not include manganese, the results of the other sampled metals indicated that, if sampled, the concentration would be extremely low or nondetected.

\section{- Radiological Carcinogenic Risk}

The total cancer risk for radiological constituents for the hypothetical on-unit industrial worker and resident exposed to surface soil $(0-1 \mathrm{ft})$ and groundwater was $1 \times 10^{-5}$ and $5 \times 10^{-5}$, respectively. The radiological carcinogenic risk is due to the ingestion of radium-228, tritium, uranium$233 / 234$, and uranium-238 in groundwater and external exposure to cesium-137 in surface soils. Radium-228, uranium-233/234, and uranium-238 were also detected in background samples which indicates that a significant portion of the estimated risks of these naturally-occurring radionuclides is the result of background conditions at the $K$ BPOP. Tritium may be ubiquitous given the nature of the SRS, Cesium-137 in soil was observed at levels consistent with global fallout activity.

\section{Ecological Risk Assessment}

The ecological risk assessment component of the BRA concluded that none one of the constituents detected in the soil at the $K$ BPOP have the potential for adverse effects to the oldfield mice that may use the unit as a foraging area. It is also - unlikely that the constituents would cause an adverse effect on the ecological community. Therefore, there are no ecological COCs at the $\mathrm{K}$ BPOP.

\section{Remedial Goal Options}

Chemical-specific remedial goal options (RGOs) are concentration goals for individual chemicals for specific media and land use scenarios at CERCLA sites. General sources of chemicalspecific RGOs include: (1) concentrations based on Applicable or Relevant and Appropriate Requirements (ARARs), and (2) concentrations based on risk values from the risk assessment. RGOs are derived for those contaminants in a pathway that result in an exceedance of a cancer risk of $1 \times 10^{-6}$ or an HI of 1.0. These constituents are defined as constituents of concern (COCs). Separate calculations are made for each of three target risk levels for both cancer and noncancer concerns. The target cancer risk levels are $1 \times 10^{-4}$, $1 \times 10^{-5}$, and $1 \times 10^{-6}$. The target HIs (noncancer) are 3,1 , and 0.1 .

Cesium-137 was determined to be the only COC at the $\mathrm{K}$ BPOP because of external radiation exposure from the surface soils for both hypothetical future residents and workers. However, the level of cesium-137 is consistent with global fallout. There are no groundwater or ecological COCs at the K BPOP. Table 4 provides a list of the RGOs for cesium-137 by receptor and medium as identified in the RU/BRA.

\section{Site-Specific Considerations}

Site-specific considerations, based orr the results of the conclusions of the RU/BRA, which suggest limited or no potential for significant risk include:

1. The miscellaneous debris at the KBPOP is covered by 4 feet of clean soil which provides an adequate barrier under the planned future use of this area.

2. Constituents detected in groundwater which led to risk and hazard exceedances for the future on-unit worker and resident are suspect due to the use of temporary piezometers. The temporary piezometers which were used to collect the groundwater samples did not have a filter pack around the screen intervals. Therefore, the samples from the piezometers were unfiltered; and, at the time of sampling, were observed to have a high turbidity factor. This high turbidity factor was believed to have caused the unusually high metal concentrations. In addition, there was only one elevated iodine-129 activity level which was believed to be a false positive reading.

Confirmatory sampling, which used permanent monitoring wells, was conducted and did not confirm the presence of these constituents in the groundwater. Therefore, the suspect contaminants were removed from the risk considerations. When they were 
Table 4. K BPOP Remedial Goals for Constituents of Concern by Receptor and Medium.

\begin{tabular}{|c|c|c|c|c|c|c|}
\hline Receptor & Media & Constituent & & Human & ealth Reme & al Goals ${ }^{2}$ \\
\hline \multirow[b]{2}{*}{ Future Worker } & \multirow[b]{2}{*}{ Soils } & \multirow[b]{2}{*}{$\mathrm{Cs}-137(\mathrm{pCi} / \mathrm{g})$} & \multirow[b]{2}{*}{ 2.61E-01 } & $1 \times 10^{-4}$ risk & $1 \times 10^{-5}$ risk & $1 \times 10^{-6}$ risk \\
\hline & & & & $1.06 \mathrm{E}+01^{b}$ & $1.06 \mathrm{E}+00^{\mathrm{b}}$ & $1.06 \mathrm{E}-01^{b}$ \\
\hline Future Resident & Soils & $\mathrm{Cs}-137(\mathrm{pCi} / \mathrm{g})$ & $2: 61 \mathrm{E}-01$ & $2.08 \mathrm{E}+00^{6}$ & $2.08 \mathrm{E}-01^{6}$ & $2.08 \mathrm{E}-02^{b}$ \\
\hline
\end{tabular}

a Calculation of human health remedial goals for noncancer hazards is not applicable to radionuclides.

b These values represent the remedial goals in soil for cesium-137 required to reach the risk level shown. 
removed from risk consideration, the calculations fall within or below the risk range of $1 \times 10^{-4}$ to $1 \times 10^{-6}$. The remaining groundwater constituents are either ubiquitous given the nature of SRS or are common laboratory artifacts. There is no risk to the groundwater from a soil leachability standpoint.

3. Cesium-137 was the primary constituent which led to exceedances in the risk calculations for soils. The activity level at which cesium- $137(0.295 \mathrm{pCi} / \mathrm{g})$ is present in the soils is consistent with activity levels of global fallout; and, cesium-137 has a half-life of 30.2 years.

4. The KBPOP does not pose a risk to the ecological community.

5. The KBPOP is located in an area which has been recommended as an industrial zone by the Citizens Advisory Board and the Savannah River Site Future Use Project Report (DOE, 1996), precluding future residential use.

\section{Remedial Action Objectives}

Remedial action objectives (RAOs) specify unitspecific contaminants, media of concern, potential exposure pathways, and remediation goals. The RAOs are based on the nature and extent of contamination, threatened resources, and the potential for human and environmental exposure. Initially, preliminary remediation goals are developed based upon ARARs, or other information from the RI/BRA. These goals should be modified, as necessary, as more information concerning the unit and potential remedial technologies become available. Final remediation goals will be determined when the remedy is selected and shall establish acceptable exposure levels that are protective of human health and the environment.

Three types of ARARs; action-, chemical-, and location-specific; have been developed to simplify identification and compliance with environmental requirements. There were no action-specific, location-specific, or chemical-specific ARARs relevant to establishing RAOs for the KBPOP.
Remedial action objectives for the KBPOP soil are as follows:

1. Reduce risks to human health via external exposure to radiological constituents (i.e., cesium-137) in the soils.

2. Achieve RGOs (see Tablè 4) established for unit soils.

There were no RAOS established for ecological receptors, or soil leachability contaminants, or groundwater contaminants since the RI/BRA data for the KBPOP indicated that these areas were not of concern for the unit.

The four feet of fill covering the miscellaneous construction debris buried at the KBPOP is adequate to be protective for direct radiation from the debris. At the time of burial, the radioactive contamination was less than $25 \mathrm{mR} / \mathrm{hr}$ with no detected alpha activity. Table 1 indicates greater than a factor of four decrease in curie content (two equivalent half curies).

\section{SECTION V}

\section{ALTERNATIVE ANALYSIS}

Section V.A Summary of the Alternatives for the K BPOP Source Control Operable Unit (Soils)

Six alternatives were considered for detailed analysis for remedial action at the K BPOP source control operable unit. Each alternative is described below:

\section{Alternative 1 - No Remedial Action}

Under this alternative, no remedial actions would be conducted and no limitations would be placed on future uses of the site. EPA policy and regulations require the consideration of a no remedial action to serve as a baseline against which the other alternatives can be compared. Because no remedial action would be taken at the unit, the K Bingham Pump Outage Pit (K BPOP) would remain in its present condition. All contaminated soils and debris are within the $K$ BPOP boundaries. The K BPOP is within the SRS facility and is not accessible to the public. The debris is covered by four feet of fill which is 
currently preventing direct contact. There would be no reduction of risk. The present worth cost of this alternative is $\$ 280,000$ which includes Record of Decision reviews every five years for thirty years.

Alternative 2 - Institutional Controls (Access and Deed Restrictions/Notifications)

Under this alternative, Institutional Controls would be implemented at the K BPOP and the site would remain undisturbed. Implementation of this alternative would require both near- and long-term actions.

In the near-term, signs would be posted at the waste unit which indicate that this area was used for disposal of waste materials and contains buried waste. In addition existing access controls would be used to maintain the use of the K BPOP for industrial use only.

Periodic inspections would be conducted and maintenance would be performed to help ensure that the cover remains intact. Maintenance, as needed, would consist of semi-annual mowing and repair of damaged fencing. Minor drainage modifications might be conducted as needed to prevent ponding and to promote surface water runoff.

In the long-term, if the property is ever transferred to non-federal ownership, the U.S. Government would, in compliance with CERCLA 120(h), create a deed for the new property owner. The deed would include notification disclosing former waste management and disposal activities as well as remedial actions taken on the site. The deed notification would, in perpetuity, notify any potential purchaser that the property has been used for the management and disposal of construction debris and other materials, including hazardous substances.

The deed would also include deed restrictions precluding residential use of the property. However, the need for these deed restrictions might be reevaluated at the time of transfer in the event that contamination no longer poses an unacceptable risk under residential use.

This alternative is shown to provide adequate protection of human health and the environment in the near-term. Long-term protection of human health and the environment would be achieved through deed restrictions and maintenance of the cover and fence. The present worth cost of this alternative is $\$ 330,000$ which includes periodic repairs to the K BPOP and Record of Decision reviews every five years for thirty years.

\section{Alternative 3 - Placement of a Soil Cover}

Under this alternative, the $\mathrm{K}$ BPOP would be covered by a low permeability soil cover with a minimum thickness of 3 feet (nominal in-place saturated hydraulic conductivity of $1 \times 10^{-5} \mathrm{~cm} / \mathrm{sec}$ or less). Limited site clearing and grading might be required to place the soil cover. The soil cover would have an upper surface with a slope of three to five percent to promote surface water runoff and minimize surface erosion. A topsoil (vegetative soil layer - minimum thickness between 3-6 inches) would be placed on top of the soil cover.

The topsoil (vegetative soil layer) would be added and area would be compacted and seeded. The topsoil would be seeded with native grasses to increase evapotranspiration. The topsoil layer would also protect the soil cover from damage due to erosion, frost, and burrowing animals. The topsoil layer would also provide water storage capacity to reduce the rate of runoff which, if too high, could cause erosion of the soil cover. Institutional controls would be necessary to restrict the area to future industrial use and to prohibit excavation of the soil cover.

This alternative is shown to provide adequate protection of human health and the environment in the near- and long-term. The contaminated material would be isolated by the soil cover and contaminant mobility would be minimized by reductions in infiltration and erosion. The present worth cost of this alternative is $\$ 650,000$ which includes labor and materials needed to place the soil cover and Record of Decision reviews every five years for thirty years.

\section{Alternative 4 - In-situ Solidification of Soil and Debris, Soil Cover}

Under this alternative, a concrete-based agent would be injected into the $\mathrm{K}$ BPOP and mixed with the soil and debris to form a solidified mass. The concrete material is injected into the ground 
in columns. The columns are placed in an overlapping pattern to provide treatment over the entire target area. The solidification process would produce a monolithic structure which would eliminate or reduce the mobility of the contaminants. A soil cover would then be placed over the treated site.

This alternative is shown to provide adequate protection of human health and the environment in the near- and long-term. The source of contamination would be removed from the $\mathrm{K}$ BPOP. The present worth cost of this alternative is $\$ 2,900,000$ which includes labor and equipment required to excavate, segregate, and dispose of $K$ BPOP debris and the costs of in-situ stabilization of site soils and construction of a soil cover. Site and soil cover maintenance and Record of Decision reviews every five years for 30 years are also included in the cost estimate.

Alternative 5 - Excavate Soil and Debris, Solidify/Stabilize Soil, Backfill Treated Soil and Debris, Soil Cover

Under this alternative, the identified soil and debris would be excavated by backhoe or other similar equipment. Excavation would extend to at least four feet below the lower boundary of the debris. The excavation could go deeper if necessary. The excavated material would then be staged at the K BPOP. Impermeable tarps would be placed on the ground prior to placement of the excavated material and similar tarps would be placed over individual piles to avoid producing airborne particulates and contaminated runoff. Other containment measures would be implemented as needed.

Debris would be separated from the soil using mechanical means such as screens and electromagnets. The excavated soil would be treated by solidification with Portland cement. The material would be mixed with the cement to form solid blocks that would reduce or eliminate the mobility of the contaminants. Preliminary testing would be required to determine an appropriate ratio of cement to soil and/or debris. The debris and treated soil would then be backfilled into the excavation and a soil cover would be placed over the K BPOP.
This alternative is shown to provide adequate protection of human health and the environment in the near- and long-term. The present worth cost of this alternative is $\$ 3,600,000$ which includes labor and materials needed to pre-treat the soil prior to excavation for waste handling purposes, to excavate and treat the soil and debris, and to construct a soil cover over the K BPOP and for Record of Decision reviews every five years for thirty years.

Alternative 6 - Excavate Soil and Debris, Dispose in E-Area Vaults or Soil/Debris Consolidation Facility (if applicable)

This alternative would require excavation by backhoe or similar means and removal of an estimated 13,150 cubic yards of soil and debris. Excavation would extend to at least four feet below the lower boundary of the debris. The excavation could go deeper if necessary. The excavated material would be hauled from the site and disposed at either the E-Area Vaults or the Soil/Debris Consolidation Facility. The excavation would be backfilled with soil and seeded.

This alternative provides overall protection of human health and the environment by removing the contamination from the $\mathrm{K}$ BPOP. This alternative meets all of the RGOs through complete source removal which eliminates the potential for long-term direct contact with contaminated soil or debris. Excavation would present limited short-term exposures to workers. The present worth cost of this alternative is $\$ 17,000,000$ which includes labor and materials needed to pre-treat soil and subsoil for waste handling purposes, to excavate the wastes, to treat the wastes following excavation for packaging and disposal requirements, to transport the waste, and to dispose of the K BPOP soil. Record of Decision reviews would not be required under this alternative because concentrations of constituents remaining at the K BPOP would not exceed RGOs.

Section V.B Summary of the Alternatives for the K BPOP Groundwater

Based on the conclusions of the K BPOP RL/BRA, groundwater alternatives were not developed as part of the K BPOP FS detailed analyses. No 
remedial action was the only alternative considered for the K BPOP groundwater.

\section{Section V.C Evaluation of the Alternatives and the Preferred Alternative}

\section{Description of Nine Evaluation Criteria}

Each of the remedial alternatives was evaluated using the nine criteria established by the National Oil and Hazardous Substances Contingency Plan (NCP). The criteria were derived from the statutory requirements of CERCLA Section 121. The NCP [40 CFR $\$ 300.430$ (e) (9)] sets forth nine evaluation criteria that provide the basis for evaluating alternatives and selecting a remedy. The criteria are:

- overall protection of human health and the environment,

- compliance with ARARs,

- long-term effectiveness and permanence,

- reduction of toxicity, mobility, or volume through treatment,

- short-term effectiveness,

- implementability,

- cost,

- state acceptance, and

- community acceptance.

In selecting the preferred alternative, the above mentioned criteria were used to evaluate the alternatives developed in the Feasibility Study for the K-Area Bingham Pump Outage Pit (643-1G) (U) (WSRC, 1997a). Seven of the criteria are used to evaluate all the alternatives, based on human health and environmental protection, cost, and feasibility issues. The preferred alternative is further evaluated based on the final two criteria: state acceptance and community acceptance. Brief descriptions of all nine criteria are given below.

Overall Protection of Human Health and the Environment - The remedial alternatives are assessed to determine the degree to which each alternative eliminates, reduces, or controls threats to human health and the environment through treatment, engineering methods, or institutional controls.

Compliance with Applicable or Relevant and Appropriate Requirements (ARARs) - ARARs are Federal and state environmental regulations that establish standards which remedial actions must meet unless waived consistent with the NCP. There are three types of ARARs: (1) chemicalspecific, (2) location-specific, and (3) actionspecific.

Chemical-specific ARARs are usually health- or risk-based levels or methodologies which, when applied to unit-specific conditions, result in the establishment of numerical values. Often these numerical values are promulgated in Federal or state regulations.

Location-specific ARARs are restrictions placed on the concentration of hazardous substances or the conduct of activities solely because they are in specific locations. Some examples of specific locations include floodplains, wetlands, historic places, and sensitive ecosystems or habitats.

Action-specific ARARs are usually technology- or remedial activity-based requirements or limitations on actions taken with respect to hazardous substances or unit-specific conditions. These requirements are triggered by the particular remedial activities that are selected to accomplish a remedy.

In addition to ARARs, compliance with other criteria, guidance, and proposed standards that are not legally binding, but may provide useful information or recommended procedures should be reviewed as To-Be-Considered when setting remedial objectives.

Long-Term Effectiveness and Permanence - The remedial alternatives are assessed based on their ability to maintain reliable protection of human health and the environment after implementation.

Reduction of Toxicity, Mobility, or Volume Through Treatment - The remedial alternatives are assessed based on the degree to which they employ treatment that reduces toxicity (the harmful nature of the contaminants), mobility (ability of the contaminants to move through the environment), or volume of contaminants associated with the unit.

Short-Term Effectiveness - The remedial alternatives are assessed considering factors relevant to implementation of the remedial action, including risks to the community during implementation, impacts on workers, potential 
environmental impacts (e.g., air emissions), and the time until protection is achieved.

Implementability - The remedial alternatives are assessed by considering the difficulty of implementing the alternative including technical feasibility, constructability, reliability of technology, ease of undertaking additional remedial actions (if required), monitoring considerations, administrative feasibility (regulatory requirements), and availability of services and materials.

Cost - The evaluation of remedial alternatives must include capital and operational and maintenance costs. Present value costs are estimated within $+50 /-30$ percent, per EPA guidance. The cost estimates given with each alternative are prepared from information available at the time of the estimate. The final costs of the project will depend on actual labor and material costs, actual site conditions, productivity, competitive market conditions, final project scope, final project schedule, and other variable factors. As a result, the final project costs may vary from the estimates presented herein.

State Acceptance - The State is requested to comment on the Remedial Investigation Report, the Baseline Risk Assessment, the Feasibility Study, and the Proposed Plan. The State's concurrence or opposition to the preferred alternative is considered.

Community Acceptance - The community acceptance of the preferred alternative is assessed by giving the public an opportunity to comment on the remedy selection process. A public comment period is held and public comments concerning the proposed remedy will be incorporated into the Responsiveness Summary of the Record of Decision.

\section{Detailed Evaluation}

The remedial action alternatives discussed in Sections V.A and V.B have been evaluated using the nine criteria just described. Table 5 presents the evaluation of the soil remedial alternatives. Groundwater remedial alternatives were not carried through a detailed evaluation.

\section{The Preferred Alternative}

The preferred alternative for the K BPOP soils is Alternative 2 - Institutional Controls (Access and Deed Restrictions/Notifications), which will restrict this land to future industrial use which would prohibit residential use of this area. Under the industrial land use scenario, external exposure to the soil at $0-1 \mathrm{ft}$. poses a risk of $3 \times 10^{-6}$ from cesium-137 for the future industrial worker. This risk level is at the lower end of the risk range of concern. Institutional Controls meets the RAOs (i.e., reduction of risk to human health via external exposure to cesium-137 in the soils) and RGOs (see Table 4) for the K BPOP soils by precluding future on-site residential use of the area, buried waste contact, removal, or excavation.

Based on the RI/BRA, there is no need for remediation of the $K$ BPOP from -an ecological standpoint.

The Institutional Controls alternative is intended to be permanent and effective in the near- and long-term. Alternative 2 is considered to have the lowest cost option which is still protective of human health and the environment.

Implementation of this alternative will require both near- and long-term actions. For the nearterm, signs will be posted at the $K$ BPOP indicating that this area was used to manage hazardous materials. In addition, existing SRS access controls will be used to maintain the use of this site for industrial use only.

In the long-term, if the property is ever transferred to non-federal ownership, the U.S. Government will, in compliance with CERCLA $120(\mathrm{~h})$, create a deed for the new property owner. The deed shall include notification disclosing former waste management and disposal activities as well as remedial actions taken on the site. The deed notification shall, in perpetuity, notify any potential purchaser that the property has been used for the management and disposal of construction debris and other materials, including hazardous substances. 


\begin{tabular}{|c|c|c|c|c|c|c|}
\hline Criteria & $\begin{array}{l}\text { Alternative } 1 \\
\text { No Remedial } \\
\text { Action }\end{array}$ & $\begin{array}{l}\text { Alternative } 2 \\
\text { Institutional } \\
\text { Controls } \\
\text { (Access \& Deed } \\
\text { Restrictions) }\end{array}$ & $\begin{array}{l}\text { Alternative } 3 \\
\text { Placement of a } \\
\text { Soil Cover }\end{array}$ & $\begin{array}{l}\text { Alternative 4 } \\
\text { In-Situ } \\
\text { Solidification of } \\
\text { Soil; Backfill } \\
\text { Treated Soil \& } \\
\text { Debris; Soil Cover }\end{array}$ & $\begin{array}{c}\text { Alternative S } \\
\text { Excavate Soil \& } \\
\text { Debris; } \\
\text { Solidification of } \\
\text { Soil; Backfill } \\
\text { Treated Soll \& } \\
\text { Debris; Soil Cover } \\
\end{array}$ & $\begin{array}{c}\text { Alternative } 6 \\
\text { Excavate Soll \& } \\
\text { Debris; Dispose at E- } \\
\text { Area Vaults or } \\
\text { Soil/Debris } \\
\text { Consolidation Facility } \\
\text { (if applicable) }\end{array}$ \\
\hline \multicolumn{7}{|c|}{ OVERALL PROTECTIVENESS } \\
\hline Human Health Protection & $\begin{array}{l}\text { Provides } \\
\text { immediate } \\
\text { protection as all } \\
\text { other alternatives, } \\
\text { but affords lower } \\
\text { longaterm } \\
\text { protection due to } \\
\text { possibility of } \\
\text { cover or site } \\
\text { development. } \\
\text { Current risks are } \\
\text { within EPA's } \\
\text { acceptable limits. }\end{array}$ & $\begin{array}{l}\text { Provides } \\
\text { immediate } \\
\text { protection } \\
\text { through access } \\
\text { restrictions; } \\
\text { provides long- } \\
\text { term protection } \\
\text { through access } \\
\text { and use } \\
\text { restrictions. }\end{array}$ & $\begin{array}{l}\text { Provides } \\
\text { immediate and } \\
\text { long-term } \\
\text { protection } \\
\text { through } \\
\text { elimination of } \\
\text { exposure } \\
\text { pathways. }\end{array}$ & $\begin{array}{l}\text { Same as Alternative } \\
3 \text {, except provides } \\
\text { additional protection } \\
\text { by solidification. }\end{array}$ & $\begin{array}{l}\text { Same as } \\
\text { Alternative } 4 .\end{array}$ & $\begin{array}{l}\text { Provides protection of } \\
\text { human health by } \\
\text { removing contaminated } \\
\text { material. }\end{array}$ \\
\hline Environmental Protection & $\begin{array}{l}\text { Lowest degree of } \\
\text { environmental } \\
\text { protection because } \\
\text { cover erosion } \\
\text { could result in } \\
\text { contaminant } \\
\text { exposure. }\end{array}$ & $\begin{array}{l}\text { Greater long: } \\
\text { term protection } \\
\text { than Alternative } \\
\text { 1 because site } \\
\text { contact would be } \\
\text { minimized. }\end{array}$ & $\begin{array}{l}\text { More than } \\
\text { Alternative } 2 \\
\text { because soll } \\
\text { cover would } \\
\text { further reduce } \\
\text { contact with } \\
\text { contaminates } \\
\text { material. } \\
\end{array}$ & $\begin{array}{l}\text { More than } \\
\text { Alternative } 3 \text { because } \\
\text { solidification would } \\
\text { further reduce } \\
\text { contact with } \\
\text { contaminants. }\end{array}$ & $\begin{array}{l}\text { Same as } \\
\text { Alternative } 4 .\end{array}$ & $\begin{array}{l}\text { Provides protection of } \\
\text { environment by } \\
\text { removing contaminated } \\
\text { material. }\end{array}$ \\
\hline \multicolumn{7}{|c|}{ COMPLIANCE WITH ARARS } \\
\hline Chemical-Specific ARARs & None identified. & $\begin{array}{l}\text { Same as } \\
\text { Alternative } 1 .\end{array}$ & $\begin{array}{l}\text { Same as } \\
\text { Alternative } 1 .\end{array}$ & $\begin{array}{l}\text { Same as Aiternative } \\
1 .\end{array}$ & $\begin{array}{l}\text { Same as } \\
\text { Alternative } 1 .\end{array}$ & Same as Alternative 1. \\
\hline Lncalion-Specific ARARs & None identified. & $\begin{array}{l}\text { Same as } \\
\text { Alternative 1. }\end{array}$ & $\begin{array}{l}\text { Same as } \\
\text { Alternative 1 }\end{array}$ & $\begin{array}{l}\text { Same as Allernative } \\
1 .\end{array}$ & $\begin{array}{l}\text { Same as } \\
\text { Alternative 1. }\end{array}$ & Same as Alternative 1 . \\
\hline
\end{tabular}




\begin{tabular}{|c|c|c|c|c|c|c|}
\hline Criteria & $\begin{array}{l}\text { Alternative } 1 \\
\text { No Remedial } \\
\text { Action }\end{array}$ & $\begin{array}{l}\text { Alternative } 2 \\
\text { Institutional } \\
\text { Controls } \\
\text { (Access \& Deed } \\
\text { Restrictions) }\end{array}$ & $\begin{array}{l}\text { Alternative } 3 \\
\text { Placement of a } \\
\text { Soil Cover }\end{array}$ & $\begin{array}{c}\text { Alternative } 4 \\
\text { In.Situ } \\
\text { Solidification of } \\
\text { Soil; Backfill } \\
\text { Treated Soil \& } \\
\text { Debris; Soil Cover }\end{array}$ & $\begin{array}{c}\text { Alternative } 5 \\
\text { Excavate Soil \& } \\
\text { Debris; } \\
\text { Solidification of } \\
\text { Soll; Backfill } \\
\text { Treated Soil \& } \\
\text { Debris; Soll Coyer } \\
\end{array}$ & $\begin{array}{c}\text { Alternative } 6 \\
\text { Excavate Soll \& } \\
\text { Debris; Dispose at E. } \\
\text { Area Vaults or } \\
\text { Soll/Debris } \\
\text { Consolidation Facillity } \\
\text { (If applicable) }\end{array}$ \\
\hline \multicolumn{7}{|c|}{ COMPLIANCE WITHI ARARS (cont'd) } \\
\hline Action-Specific ARAR.S & None identified. & None identified. & $\begin{array}{l}\text { Meets all } \\
\text { identificd } \\
\text { ARARs. }\end{array}$ & $\begin{array}{l}\text { Same as Alternative } \\
\text { 3. }\end{array}$ & $\begin{array}{l}\text { Same as } \\
\text { Alternative } 3 .\end{array}$ & Same as Alternative 3. \\
\hline \multicolumn{7}{|c|}{ LONG.TERM EFEECTIVENESS AND PERMANENCE } \\
\hline Magnilude of Residual Risk & $\begin{array}{l}\text { Least reduction of } \\
\text { all alternatives } \\
\text { because no } \\
\text { reduction would } \\
\text { occur and threat } \\
\text { could increase if } \\
\text { site is not } \\
\text { maintained. } \\
\text { Current risk is } \\
\text { within EPA's } \\
\text { acceptable limits. }\end{array}$ & $\begin{array}{l}\text { Slightly less } \\
\text { than Alternative } \\
1 \text { because site } \\
\text { would be } \\
\text { maintained. }\end{array}$ & $\begin{array}{l}\text { Same as } \\
\text { Alternative } 2 \text {. }\end{array}$ & $\begin{array}{l}\text { Same as Alternative } \\
2 .\end{array}$ & $\begin{array}{l}\text { Same as } \\
\text { Alternative } 2 \text {. }\end{array}$ & $\begin{array}{l}\text { Greatest protection } \\
\text { because all } \\
\text { contaminated material } \\
\text { is removed. }\end{array}$ \\
\hline $\begin{array}{l}\text { Adequacy and Reliability of } \\
\text { Controls }\end{array}$ & No Controls. & $\begin{array}{l}\text { Controls can } \\
\text { prevent contact } \\
\text { with } \\
\text { contaminated } \\
\text { media. } \\
\end{array}$ & $\begin{array}{l}\text { More reliable } \\
\text { than Alternative } \\
\text { 2. }\end{array}$ & $\begin{array}{l}\text { More reliable than } \\
\text { Alternative } 3 \text {. }\end{array}$ & $\begin{array}{l}\text { Same as } \\
\text { Alternative 4. }\end{array}$ & $\begin{array}{l}\text { Greatest reliability } \\
\text { because all } \\
\text { contaminated material } \\
\text { is removed. }\end{array}$ \\
\hline Need for S-year Review & $\begin{array}{l}\text { All alternatives } \\
\text { except } 6 \text { requires } \\
\text { 5-year review. }\end{array}$ & $\begin{array}{l}\text { All alternatives } \\
\text { except } 6 \text { requires } \\
\text { 5-year review. }\end{array}$ & $\begin{array}{l}\text { All alternatives } \\
\text { except } 6 \text { requires } \\
\text { 5-year review. }\end{array}$ & $\begin{array}{l}\text { All alternatives } 1 \\
\text { except } 6 \text { requires } 5 \text {. } \\
\text { year review. }\end{array}$ & $\begin{array}{l}\text { Aill altematives } \\
\text { except } 6 \text { requires } \\
\text { 5-year review. }\end{array}$ & $\begin{array}{l}\text { No review is necessary } \\
\text { because no waste would } \\
\text { remain at } \mathrm{K} \text { BPOP. }\end{array}$ \\
\hline \multicolumn{7}{|c|}{ REDUCTION OF TOXICITX, MOBILITX, AND VOLUME THROUGH TREATMENT } \\
\hline Treatmen! Process Used & None. & None. & None. & $\begin{array}{l}\text { Directly treats } \\
\text { inorganics. }\end{array}$ & $\begin{array}{l}\text { Same as } \\
\text { Alternadive } 4 .\end{array}$ & None: \\
\hline
\end{tabular}




\begin{tabular}{|c|c|c|c|c|c|c|}
\hline Criteria & $\begin{array}{l}\text { Alternative } 1 \\
\text { No Remedial } \\
\text { Action. }\end{array}$ & $\begin{array}{l}\text { Alternative } 2 \\
\text { Institutional } \\
\text { Controls } \\
\text { (Access \& Deed } \\
\text { Restrictions) }\end{array}$ & $\begin{array}{l}\text { Alternative } 3 \\
\text { Placement of a } \\
\text { Soil Cover }\end{array}$ & $\begin{array}{l}\text { Alternative } 4 \\
\text { In-Situ } \\
\text { Solidification of } \\
\text { Söll; Backfill } \\
\text { Treated Soll \& } \\
\text { Debris; Soll Cover }\end{array}$ & $\begin{array}{c}\text { Alternative 5 } \\
\text { Excavate Soll \& } \\
\text { Debris; } \\
\text { Solldiffication of } \\
\text { Soll; Backfill } \\
\text { Treated Soll \& } \\
\text { Debris; Soll Cover } \\
\end{array}$ & $\begin{array}{l}\text { Alternative } 6 \\
\text { Excavate Soil \& } \\
\text { Debris; Dispose at } E \text {. } \\
\text { Area Vaults or } \\
\text { SoliDebris } \\
\text { Consolidation Facility } \\
\text { (if applicable) }\end{array}$ \\
\hline \multicolumn{7}{|c|}{ REDUCTION OF TOXICITY, MOBILITY, AND YOLUME THROUGH TREATMENT (cOnt'd) } \\
\hline Amount Destroyed or Treated & None. & None. & None. & $\begin{array}{l}\text { Treats all inorganics } \\
\text { within site, but total } \\
\text { mass of organics } \\
\text { remains the same. }\end{array}$ & $\begin{array}{l}\text { Same as } \\
\text { Alternative } 4 .\end{array}$ & None. \\
\hline $\begin{array}{l}\text { Reduction of Toxicity, Mobility, } \\
\text { or Volume Through Treatment }\end{array}$ & None. & None. & $\begin{array}{l}\text { Mobility of } \\
\text { contaminants } \\
\text { reduced by soil } \\
\text { cover. }\end{array}$ & $\begin{array}{l}\text { Volume of } \\
\text { contaminated } \\
\text { material would be } \\
\text { increased by up to } \\
100 \% \text { of the original } \\
\text { volume; mobility of } \\
\text { contaminants would } \\
\text { be less than under } \\
\text { Alternative } 3 .\end{array}$ & $\begin{array}{l}\text { Same as } \\
\text { Alternative 4, } \\
\text { except debris } \\
\text { would not be } \\
\text { treated by } \\
\text { solldification. }\end{array}$ & None. \\
\hline Irreversible Treatment & $\begin{array}{l}\text { Not applicable; no } \\
\text { treatment. }\end{array}$ & $\begin{array}{l}\text { Not applicable; } \\
\text { no treatment. }\end{array}$ & $\begin{array}{l}\text { Not applicable; } \\
\text { no treatment. }\end{array}$ & $\begin{array}{l}\text { No further remedies } \\
\text { could be undertaken } \\
\text { on the treated } \\
\text { material. }\end{array}$ & $\begin{array}{l}\text { Same as } \\
\text { Alternative 4. }\end{array}$ & $\begin{array}{l}\text { Material would be } \\
\text { removed. }\end{array}$ \\
\hline $\begin{array}{l}\text { Type and Quantiry of Residuals } \\
\text { Remaining after Treatment }\end{array}$ & $\begin{array}{l}\text { Not applicable; no } \\
\text { treatment. }\end{array}$ & $\begin{array}{l}\text { Not applicable; } \\
\text { no treatment. }\end{array}$ & $\begin{array}{l}\text { Not applicable; } \\
\text { no treatment. }\end{array}$ & $\begin{array}{l}\text { Same remaining } \\
\text { residuals as } \\
\text { Alternatives } 1 \\
\text { through } 3 \text {, but , } \\
\text { volume would } \\
\text { increase \& residuals } \\
\text { would be solidified. }\end{array}$ & $\begin{array}{l}\text { Same as } \\
\text { Alternative 4. }\end{array}$ & $\begin{array}{l}\text { Not applicable; no } \\
\text { treatment. }\end{array}$ \\
\hline
\end{tabular}


Table 5 Comparative Analysis of Remedial Alternatives Considered for the K BPOP Source Control Operable Unit (cont'd).

\begin{tabular}{|c|c|c|c|c|}
\hline 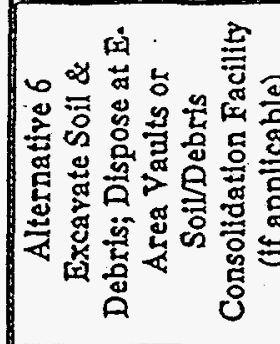 & 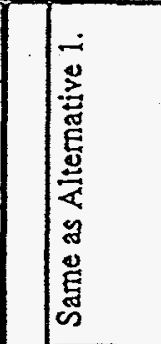 & 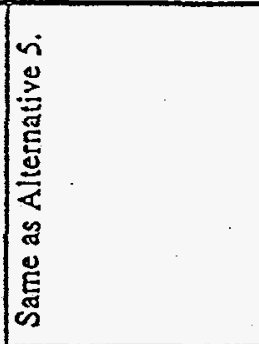 & 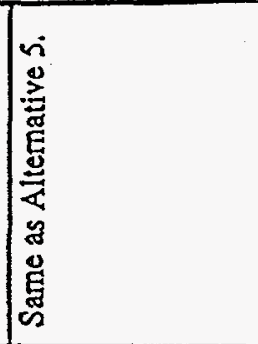 & 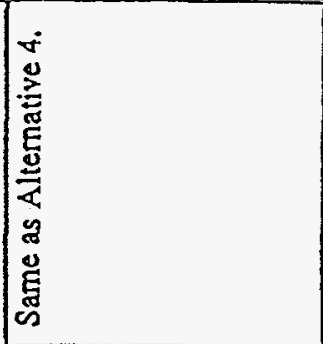 \\
\hline 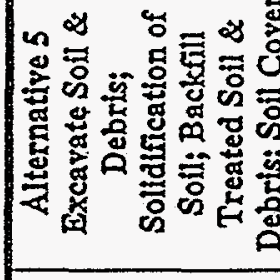 & 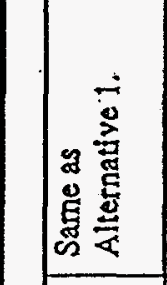 & 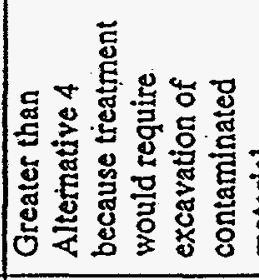 & 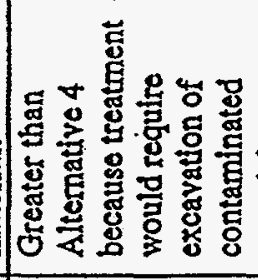 & 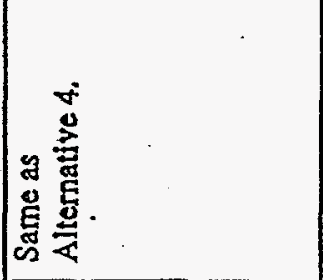 \\
\hline 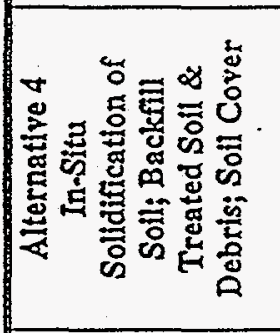 & 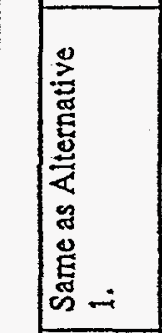 & 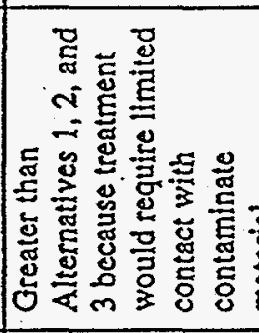 & 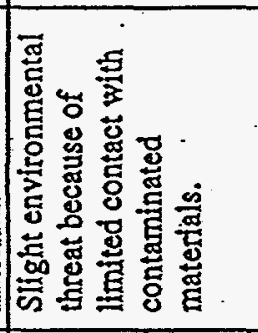 & 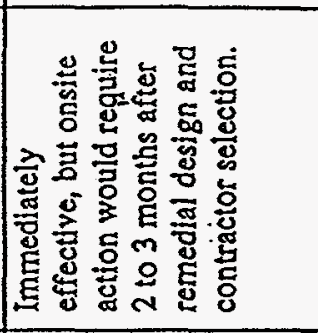 \\
\hline 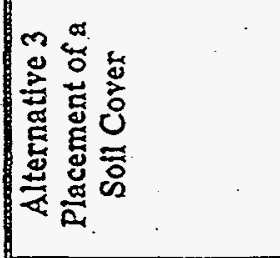 & 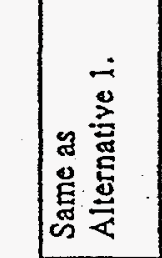 & 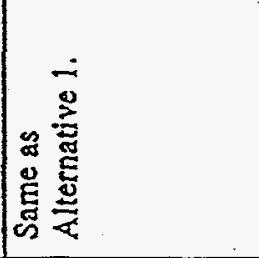 & 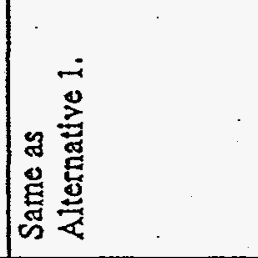 & 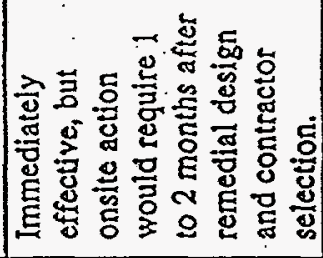 \\
\hline 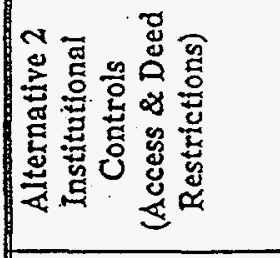 & 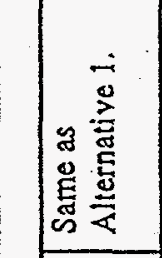 & 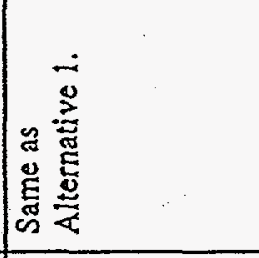 & 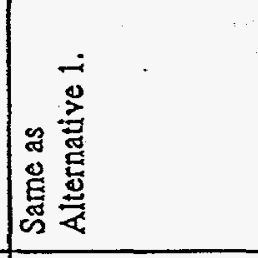 & \\
\hline 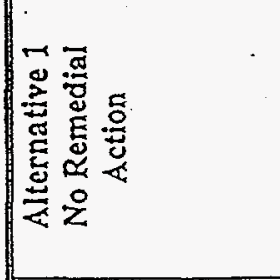 & 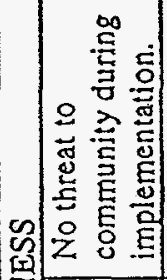 & 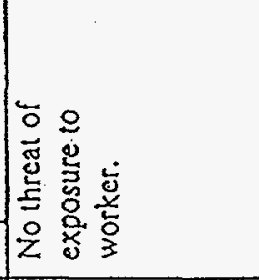 & 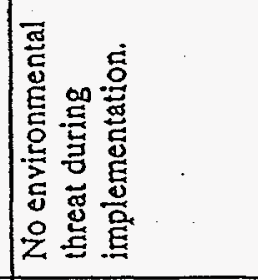 & 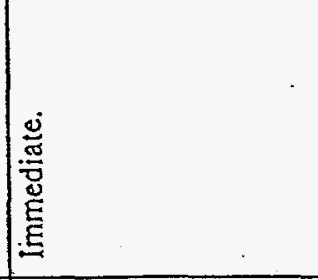 \\
\hline 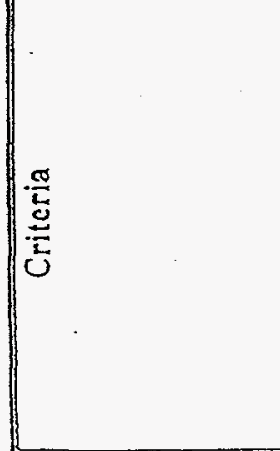 & 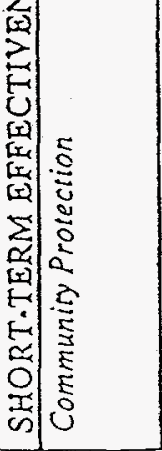 & 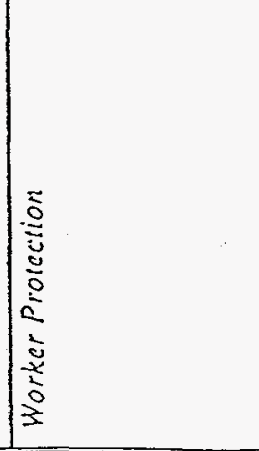 & 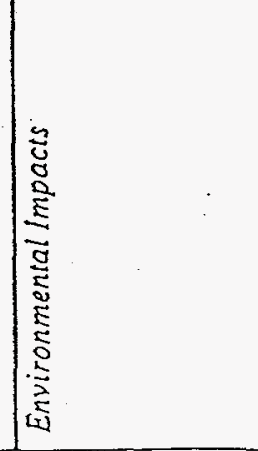 & 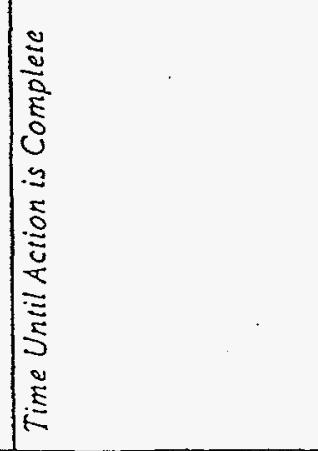 \\
\hline
\end{tabular}




\begin{tabular}{|c|c|c|c|c|c|c|}
\hline Criteria & $\begin{array}{l}\text { Alternative } 1 \\
\text { No Remedial } \\
\text { Action }\end{array}$ & $\begin{array}{l}\text { Alternative } 2 \\
\text { Institutional } \\
\text { Controls } \\
\text { (Access \& Deed } \\
\text { Restrictions) }\end{array}$ & $\begin{array}{l}\text { Alternative } 3 \\
\text { Placement of a } \\
\text { Soll Cover }\end{array}$ & $\begin{array}{c}\text { Alternative } 4 \\
\text { In-Situ } \\
\text { Solidification of } \\
\text { Soil; Backfill } \\
\text { Treated Soll \& } \\
\text { Debris; Soll Cover }\end{array}$ & $\begin{array}{c}\text { Alternative } 5 \\
\text { Excayate Soil \& } \\
\text { Debris; } \\
\text { Solidification of } \\
\text { Soll; Backfill } \\
\text { Treated Soll \& } \\
\text { Debris; Soll Cover }\end{array}$ & $\begin{array}{c}\text { Alternative } 6 \\
\text { Excavate Soil \& } \\
\text { Debris; Dispose at E. } \\
\text { Area Vaults or } \\
\text { Soll/Debris } \\
\text { Consolidation Facility } \\
\text { (If applicable) }\end{array}$ \\
\hline \multicolumn{7}{|l|}{ IMPLEMENTABILITY } \\
\hline $\begin{array}{l}\text { Ability } 10 \text { Construct and } \\
\text { Operase }\end{array}$ & $\begin{array}{l}\text { No construction or } \\
\text { operation. }\end{array}$ & $\begin{array}{l}\text { Same as } \\
\text { Alternative } 1 .\end{array}$ & $\begin{array}{l}\text { Simple to } \\
\text { construct and } \\
\text { maintain. }\end{array}$ & $\begin{array}{l}\text { More difficult than } \\
\text { Alternative } 3 \text { because } \\
\text { special equipment is } \\
\text { required for } \\
\text { treatment. }\end{array}$ & $\begin{array}{l}\text { Similar to } \\
\text { Alternative } 4 .\end{array}$ & $\begin{array}{l}\text { Requires regulatory } \\
\text { evaluation and } \\
\text { comparison to waste } \\
\text { acceptance criteria. }\end{array}$ \\
\hline $\begin{array}{l}\text { Ease of Doing More Action if } \\
\text { Needed }\end{array}$ & $\begin{array}{l}\text { Additional action } \\
\text { easily } \\
\text { implemented. }\end{array}$ & $\begin{array}{l}\text { Same as } \\
\text { Alternative } 1 .\end{array}$ & $\begin{array}{l}\text { Same as } \\
\text { Alternative } 1 .\end{array}$ & $\begin{array}{l}\text { No further remedies } \\
\text { could be undertaken } \\
\text { on treated waste. }\end{array}$ & $\begin{array}{l}\text { Same as } \\
\text { Alternative } 4 .\end{array}$ & $\begin{array}{l}\text { Contaminated material } \\
\text { would be removed from } \\
\text { site, so additional } \\
\text { remedies would not be } \\
\text { necessary. }\end{array}$ \\
\hline Ability to Monitor Effectiveness & $\begin{array}{l}\text { Alternative } \\
\text { includes no } \\
\text { monitoring; future } \\
\text { exposure could } \\
\text { occur in absence } \\
\text { of controls: } \\
\end{array}$ & $\begin{array}{l}\text { Frequent } \\
\text { inspection of } \\
\text { property would } \\
\text { provide notice of } \\
\text { changes. }\end{array}$ & $\begin{array}{l}\text { Same as } \\
\text { Alternative } 2 .\end{array}$ & $\begin{array}{l}\text { Same as Alternative } \\
2 \text {, except } \\
\text { effectiveness of } \\
\text { solidification would } \\
\text { not be monitored. }\end{array}$ & $\begin{array}{l}\text { Same as } \\
\text { Alternative } 4 .\end{array}$ & $\begin{array}{l}\text { No need to monitor } \\
\text { because waste would } \\
\text { not remain on site. }\end{array}$ \\
\hline $\begin{array}{l}\text { Availability of Services and } \\
\text { Equipment }\end{array}$ & $\begin{array}{l}\text { No services or } \\
\text { equipment } \\
\text { needed. }\end{array}$ & $\begin{array}{l}\text { Services are } \\
\text { available locally. }\end{array}$ & $\begin{array}{l}\text { Services and } \\
\text { equipment are } \\
\text { available. }\end{array}$ & $\begin{array}{l}\text { Less than Alternative } \\
3 \text {, longer lead time } \\
\text { may be needed to } \\
\text { secure services and } \\
\text { equipment. }\end{array}$ & $\begin{array}{l}\text { Same as } \\
\text { Alternative } 4 .\end{array}$ & Same as Alternative 4. \\
\hline \multicolumn{7}{|l|}{ COSI } \\
\hline Capital Cost & $\$ 0$ & $\$ 31,000$ & $\$ 330,000$ & $\$ 2,600,000$ & $\$ 3,300,000$ & $\$ 17,000,000$ \\
\hline First Year O\& $M$ Cost & $\$ 0$ & $\$ 1,700$ & $\$ 2,600$ & $\$ 2,600$ & $\$ 2,600$ & so \\
\hline Present WORTH & $\$ 280,000$ & $\$ 330,000$ & $\$ 650,000$ & $\$ 2,900,000$ & $\$ 3,600,000$ & $\$ 17,000,000$ \\
\hline
\end{tabular}


The deed shall also include deed restrictions precluding residential use of the property. However, the need for deed restrictions may be reevaluated at the time of transfer in the event that contamination no longer poses an unacceptable risk under residential use.

Throughout the period of Federal ownership, as well as for any future ownership, under Institutional Controls (Alternative 2), there will be no risk greater than $3 \times 10^{-6}$ to the future industrial worker. Furthermore, there will be no appreciable risk to the environment.

Based on the conclusions of the RIBRA, the preferred remedial alternative for the $K$ BPOP groundwater is no remedial action. The groundwater contaminants detected in the initial groundwater sampling using data obtained with temporary piezometers were the result of silty samples and were not confirmed when the groundwater was sampled using permanent monitoring wells.

This proposal is consistent with EPA guidance and is an effective use of risk management principles. This Proposed Plan provides for involvement with the community through a document review process and a public comment period. As previously discussed, public input will be documented in the Responsiveness Summary of the K BPOP Record of Decision.

\section{SECTION VI}

\section{POST-ROD DOCUMENT SCHEDULE}

Since Institutional Controls is the preferred remedial alternative for the $\mathrm{K} B P O P$, a Corrective Measures Implementation/ Remedial Action Report (CM/RAR) will be submitted for EPA and SCDHEC review after issuance of the $K$ BPOP ROD. The CMI/RAR describes the measures that will be taken for implementation of Institutional Controls at the K BPOP.

The post-ROD document schedule is described below and is illustrated in Figure 7:

1. CMU/RAR (rev. 0) for the K BPOP will be submitted for EPA and SCDHEC review four months after issuance of the ROD.
2. EPA and SCDHEC review of the $K$ BPOP CMI/RAR (rev. 0) - 90 days.

3. SRS revision of the K BPOP CMI/RAR (rev. 0 ) after receipt of regulatory comments - 60 days.

4. EPA and SCDHEC final review and approval of the K BPOP CMI/RAR (rev. 1) - 30 days. 


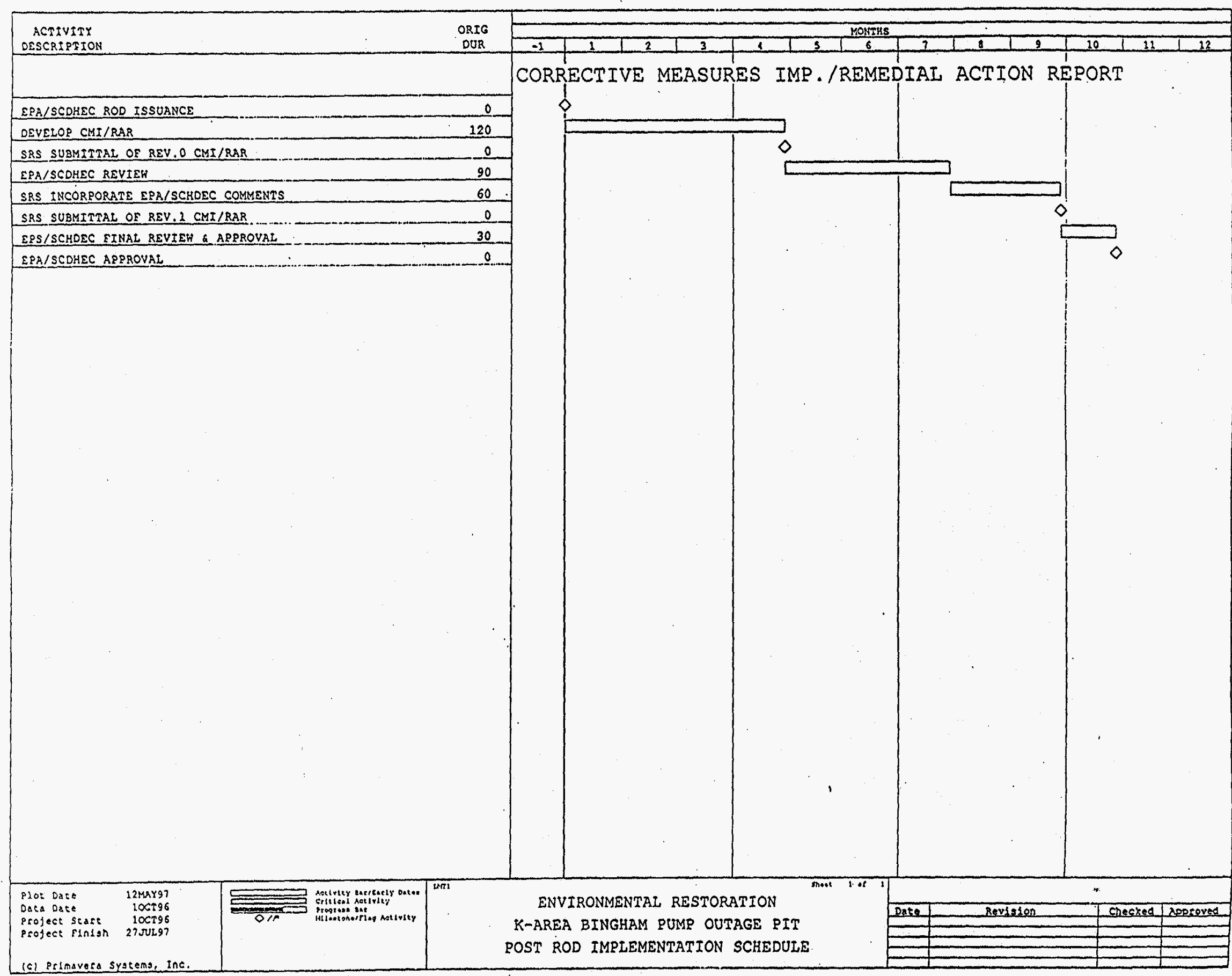




\section{REFERENCES}

DOE (U.S. Department of Energy), 1994. Public Involvement, A Plan for the Savannah River Site. Savannah River Operations Office, Aiken, South Carolina (1994).

DOE, 1996. Savannah River Site Future Use Project Report, Stakeholder Recommendations for Savannah River Site Land and Facilities (U). Savannah River Operations Office, Aiken, South Carolina (January 1996).

FFA, 1993. Federal Facility Agreement for the Savannah River Site, Administrative Docket No. 89-05-FF, (Effective Date: August 16, 1993).

WSRC (Westinghouse Savannah River Company), 1997a. Feasibility Study for the K-Area Bingham Pump Outage Pit (643-IG) (U). WSRC-RP-96-831, Rev. 1.1, Westinghouse Savannah River Company, Aiken, South Carolina (March 1997).

WSRC (Westinghouse Savannah River Company), 1997b. Remedial Investigation Report With Baseline Risk Assessment for the K-Area Bingham Pump Outage Pit (643-1G) (U). WSRC-RP-95-1555, Rev. 1.2, Westinghouse Savannah River Company, Aiken, South Carolina (February 1997). 


\section{GLOSSARY}

Administrative Record File: A file that is maintained and contains all information used to make a decision on the selection of a response action under the Comprehensive Environmental Response, Compensation, and Liability Act. This file is to be available for public review, and a copy is to be established at or near the Site, usually at one of the information repositories. Also, a duplicate file is held in a central location, such as a regional or state office.

Applicable or Relevant and Appropriate Requirements (ARARs): Refers to the federal and state requirements that a selected remedy will attain. These requirements may vary from site to site.

Baseline Risk Assessment (BRA): Analysis of the potential adverse health effects (current or future) caused by hazardous substance release from a site in the absence of any actions to control or mitigate the release.

Capital Costs: Money spent for long-term additions or improvements and charged to a capital assets account.

Characterization: The compilation of all available data about the waste units to determine the rate and extent of contaminant migration resulting from the waste site, and the concentration of any contaminants that may be present.

Chemicals of Concern (COCs): Site- and mediaspecific, man-made and naturally occurring inorganic and organic chemicals, pesticides, and radionuclides detected at a waste unit during the RI/BRA and found to contribute to a pathway having a hazard quotient greater than 1.0 or a carcinogenic risk greater than $10^{-6}$ during the BRA.

Comprehensive Environmental Response, Compensation, and Liability Act (CERCLA): A Federal Law passed in 1980 and modified in 1986 by the Superfund Amendments Reauthorization Act. The Acts created a special fund that goes into a Trust Fund, commonly known as Superfund, to investigate and clean up abandoned or uncontrolled hazardous waste sites.
Contamination: The deposition of unwanted chemical and/or radioactive material at a site.

Corrective Action: An EPA requirement to conduct remedial procedures under RCRA 3998(h) at a facility when there has been a release of hazardous waste or constituents into the environment. Corrective action may be required beyond the facility boundary and can be required regardless of when the waste was placed at the facility.

Exposure: Contact of an organism with a chemical or physical agent. Exposure is quantified as the amount of the agent available at the exchange boundaries of the organism (e.g., skin, lungs, digestive tract, etc.) and available for absorption.

Feasibility Study (FS): A two phase study under CERCLA to (1) develop a range of technologies/process options which can be utilized for the remediation of the recognized COCs at a specific waste site; and (2) the comparative analysis of these options. The FS may be conducted concurrently with the RI/BRA.

Federal Facility Agreement (FFA): The legally binding agreement between regulatory agencies (EPA and SCDHEC) and regulated entities (DOE) that sets the standards and schedules for the comprehensive remediation of the SRS.

Media: A pathway through which contaminants are transferred. Five media by which contaminants may be transferred are groundwater, soil, surface water, sediments, and air.

National Priorities List (NPL): Formal listing of the nation's worst contaminated sites, as established by the Comprehensive Environmental Response, Compensation, and Liability Act.

Operable Unit: Defined in the regulations as a discrete action taken as one part of an overall site cleanup. The term is also used in EPA guidance documents to refer to distinct geographic areas or media-specific units within a site. A number of operable units can be used in the course of a cleanup. 
Operation and Maintenance (O\&M): Activities conducted at a site after a response action occurs to ensure that the cleanup and/or systems are functioning properly.

Overall Protection of Human Health and the Environment: The assessment against this criterion describes how the alternative, as a whole, achieves and maintains protection of human health and the environment.

Proposed Plan (PP): A legal document that provides a brief analysis of remedial alternatives under consideration for the site/operable unit and proposes the preferred alternative. The public will have a chance to review and comment on all alternatives under consideration in the proposed plan.

Reduction of Toxicity, Mobility, and Volume through Treatment: The assessment against this criterion evaluates the anticipated performance of the specific treatment technologies an alternative may employ.

Record of Decision (ROD): A legal document that describes the final remedial actions selected for a site, why the remedial actions were chosen, and how the public responded to the proposed remedial actions.

Responsiveness Summary: A summary of oral and/or written comments received during the proposed plan comment period. The Responsiveness Summary highlights community concerns and is a key part of the ROD.

Remedial Investigation (RI): The investigation conducted at a waste unit to determine the extent and magnitude of a hazardous substance release from the waste site to any environmental media. Information generated in the investigation is utilized in the BRA. The results of the investigation are documented in the RI/BRA Report.

Superfund: The common name used for the Comprehensive Environmental Response, Compensation, and Liability Act. The Superfund program was established to help fund cleanup of hazardous waste sites. It also allows for legal action to force those responsible for the sites to clean them up. 